\title{
Rhenium and Technetium Complexes of Thioamide Derivatives of Pyridylhydrazine that Bind to Amyloid- Plaques
}

Scott E. Fletcher, ${ }^{a}$ Asif Noor, ${ }^{a}$ James L. Hickey, ${ }^{a}$ Catriona A. McLean, ${ }^{b}$ Jonathan M. White ${ }^{a}$ and Paul S. Donnelly ${ }^{\mathrm{*}} *$

${ }^{a}$ School of Chemistry and Bio21 Molecular Science and Biotechnology Institute, University of Melbourne, Melbourne, Victoria, Australia, 3010.

${ }^{b}$ Department of Anatomical Pathology, The Alfred Hospital, Victoria 3181, Australia, and The Florey Institute of Neuroscience and Mental Health, University of Melbourne, Parkville, Melbourne, Victoria, 3052, Australia.

Contact:pauld@unimelb.edu.au

\begin{abstract}
Age-associated deposition of amyloid- in cerebral blood vessels, a condition referred to as cerebral amyloid angiopathy, can contribute to stroke and dementia. This research aimed to design new radioactive technetium- $99 \mathrm{~m}$ complexes that bind to amyloid- plaques that have the potential to assist in diagnosis of cerebral amyloid angiopathy using single photon emitted computed tomography (SPECT) imaging. Six new pyridylthiosemicarbazide ligands containing either benzofuran or styrylpyridyl functional groups that are known to selectively bind to amyloid plaques were prepared. Nonradioactive isotopes of technetium are not available so rhenium was used as a surrogate for exploratory chemistry. The new ligands were used to prepare well defined [Re-oxo] ${ }^{3+}$ complexes where two pyridylthiosemicarbazide ligands were coordinated to a single metal ion to give bivalent complexes with two amyloid- targeting functional groups. The interaction of the [Reoxo $]^{3+}$ complexes with synthetic amyloid- ${ }_{1-42}$ and with amyloid plaques in human brain tissue was investigated. Two ligands were selected to develop methods to prepare their $\left[{ }^{99 \mathrm{~m}} \mathrm{Tc} \text {-oxo }\right]^{3+}$ complexes at the tracer level. These technetium-99m complexes are likely to be isostructural to their rhenium-oxo analogues.
\end{abstract}

\section{Introduction}

Deposition of -amyloid in cerebral blood vessels, referred to as cerebral amyloid angiopathy (CAA), may contribute to intracerebral haemorrhage (12\% of clinical presentations).[1, 2] Microhaemorrhages and microinfarcts may also occur due to CAA.[3] -amyloid (A ) is a 39-43 
amino acid peptide derived from the amyloid precursor protein. CAA results in changes to the morphology of the cerebral blood vessels, the deposition and hardening of A aggregates is thought to contribute to microbleeds, haemorrhagic stroke and vascular cognitive impairment.[4, 5] A noninvasive test to help diagnose CAA has the potential to be clinically useful.[6].

The deposition of aggregates of $\mathrm{A}$ in brain tissue to form extracellular plaques is also a pathological feature of Alzheimer's disease (AD) and in some instances CAA and AD appear to be related. Recent developments have enabled non-invasive assessment of amyloid burden in AD subjects using positron emission tomography (PET) and radiolabeled tracers that bind to A $\beta$ plaques. One of the first tracers used for A $\beta$ imaging in humans was a benzothiazole derivative radiolabeled with the positron-emitting carbon-11 isotope known by the trivial name of $\left[{ }^{11} \mathrm{C}\right] \mathrm{PIB}$ (Pittsburgh compound B; Figure 1).[7-9] [ $\left.{ }^{11} \mathrm{C}\right] \mathrm{PIB}$ has also been investigated for the detection of amyloid in CAA but the ability of $\left[{ }^{11} \mathrm{C}\right] \mathrm{PIB}$ to cross the blood-brain barrier makes it difficult to distinguish $\mathrm{A} \beta$ deposits within blood vessels from those in the cerebral parenchyma.[4, 10] Imaging agents that can differentiate between A deposits on the walls of cerebral blood vessels from A plaques in the brain parenchyma may help in non-invasive diagnosis of CAA.[6]

The interaction between benzothiazole derivatives such as $\left[{ }^{11} \mathrm{C}\right]-\mathrm{PIB}$ and $\mathrm{A} \beta$ plaques and fibrils is thought to be due to a combination of hydrophobic and hydrogen-bonding interactions. Stilbene and styrylpyridyl derivatives are structurally related to benzothiazoles and also exhibit selective binding to $A \beta$ plaques. Efforts focusing on the preparation of stilbene or styrylpyridyl derivatives radiolabeled with positron-emitting fluorine-18 resulted in the FDA approval of $\left[{ }^{18}\right.$ F]AV45 (Florbetapir; Figure 1) to detect the presence of amyloid.[11-15] Pioneering work directed toward developing PET probes to help diagnose CAA investigated a series of ${ }^{18} \mathrm{~F}$ labelled styrylpyridyl derivatives with high molecular weights designed to selectively target A plaques in the blood vessels of the brain but not cross the blood-brain barrier.[6]

Latest developments have identified 2-pyridylbenzofuran derivatives as A plaque imaging agents with lower non-specific binding and consequently superior sensitivity when compared to benzothiazole and styrylpyridyl ligands. An exhaustive synthetic chemistry program led by AstraZeneca has identified AZD 4694 as a lead candidate with better sensitivity for amyloid due to low white matter binding and high cortical binding (Figure 1).[16, 17] 


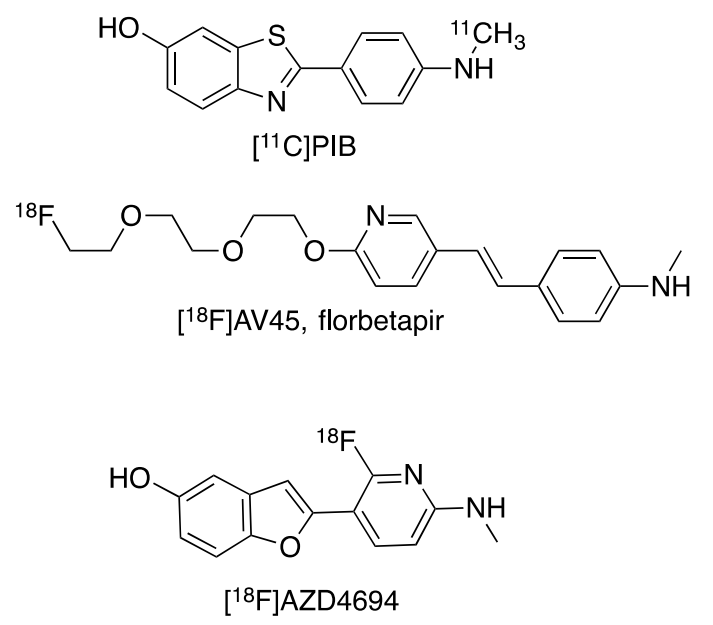

Figure 1. Amyloid imaging agents, [ $\left.{ }^{11} \mathrm{C}\right] \mathrm{PIB}$, florbetapir and AZD 4694.

Despite recent concerns over production related shortages of technetium- $99 \mathrm{~m}$ single photon computed emission tomography (SPECT) imaging retains its importance to nuclear medicine. Technetium-99m is used in over $80 \%$ of nuclear imaging procedures worldwide. The technetium$99 \mathrm{~m}$ isotope emits $\mathrm{y}$-rays $(140 \mathrm{keV})$ with a half-life of 6 hours. The clinical development of technetium-99m complexes that bind to A plaques would result in significant developments in diagnostic imaging of $\mathrm{AD}$ and CAA.[18-20] A wide variety of technetium-99m complexes and their rhenium analogues have been prepared that are capable of binding to A plaques.[21-31] An excellent recent comprehensive review of the area is available.[20]

Complexes where a tridentate ligand bearing either a benzothioazole or stilbene derivatives is coordinated to the $\left[\mathrm{Tc}(\mathrm{CO})_{3}\right]^{+}$core $[28,32]$ and $[\mathrm{TcO}]^{3+}$ complexes coordinated to two bidentate hydroxyamamide ligands[33, 34] that bind A plaques but do not cross the blood-brain barrier have demonstrated the potential for diagnostic imaging of CAA using technetium-99m complexes. In this work we prepare pyridylthiosemicarbazide ligands with appended stilbene and benzofuran derivatives. The new ligands are then used to form well defined complexes where two substituted pyridylthiosemicarbazide ligands coordinate to a single $[\mathrm{MO}]^{3+}$ core $(\mathrm{M}=\mathrm{Re}$ or $99 \mathrm{mTc})$ and investigate the A binding of the new complexes. There are no stable isotopes of technetium available so the group VII congener, rhenium, was used in exploratory synthesis and characterization. A goal was that the relatively high molecular weight of these bivalent (possessing two targeting groups) complexes and their nominal positive charge would preclude penetration of the blood-brain barrier whilst retaining affinity for vascular A .

\section{Results and Discussion}

Modification of the terminal hydrazinic nitrogen of hydrazinopyridyl derivatives with an additional thiourea functional group results in a substituted pyridylthiocarbazide ligand system that is capable 
of forming well-defined, stable complexes with two ligands bound to a single $[\mathrm{MO}]^{3+}(\mathrm{M}=\mathrm{Re}$ or ${ }^{99 \mathrm{~m}} \mathrm{Tc}$ ) cores. These new pyridylthiocarbazide ligands can be considered as sulfur containing variations to 6-hydrazinonicotinamide (HYNIC) derivatives leading to them being given the trivial name of SHYNIC ligands.[35] This ligand system can be functionalized in a similar fashion to HYNIC for example, by attaching tumour targeting peptides such as cylic-RGD or $\mathrm{Tyr}^{3}$ octreotate.[36] In this work, we incorporate styrylpyridyl or benzofuran functional groups, that are known to binds to A plaques, into the ligand framework with a view to forming $[\mathrm{MO}]^{3+}\left(\mathrm{M}={ }^{99 \mathrm{~m}} \mathrm{Tc}\right.$ or Re) complexes featuring two plaque targeting groups. It has been suggested that such bivalent targeting molecules have increased affinity for molecular targets.

The benzofuran containing ligands, $\mathrm{H}_{2} \mathbf{L}^{1-4}$ (Figure 2), were synthesised from 5methoxybenzofuran. Lithiation of 5-methoxybenzofuran with $n$-butyllithium followed by treatment with triisopropyl borate allowed isolation of the corresponding boronic acid 1. This boronic acid was used in a Suzuki coupling reaction with 2-chloro-5-iodopyridine to form compound 2. Treatment of compound $\mathbf{2}$ with hydrazine hydrate afforded the substituted hydrazine $\mathbf{4}$. Reaction of 4 with either methylisothiocyante or $N, N$-dimethylaminoethylisothiocyanate produced $\mathrm{H}_{2} \mathbf{L}^{1}$ and $\mathrm{H}_{2} \mathbf{L}^{2}$ respectively. Deprotection of $\mathbf{2}$ with boron tribromide to produce $\mathbf{3}$, followed by treatment with hydrazine and either methylisothiocyante or $N, N$-dimethylaminoethylisothiocyanate allowed isolated of $\mathrm{H}_{2} \mathbf{L}^{3}$ and $\mathrm{H}_{2} \mathrm{~L}^{4}$. The N,N-dimethylaminoethyl functional groups in $\mathrm{H}_{2} \mathbf{L}^{2}$ and $\mathrm{H}_{2} \mathbf{L}^{4}$ were added to improve the solubility of the ligands and metal complexes in aqueous mixtures.

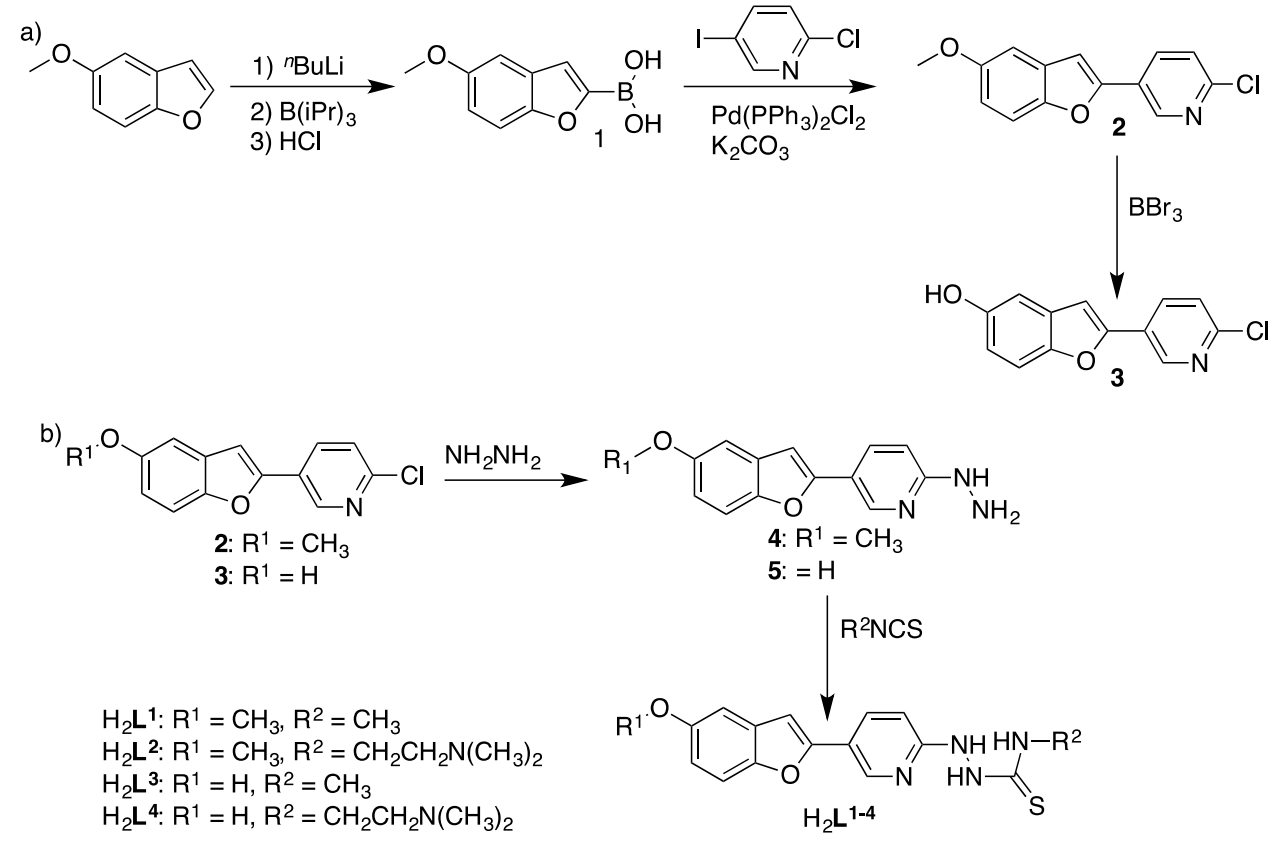

Figure 2. Synthesis of $\mathrm{H}_{2} \mathbf{L}^{1-4}$.

The synthesis of the styrylpyridyl ligands $\mathrm{H}_{2} \mathbf{L}^{5}$ and $\mathrm{H}_{2} \mathbf{L}^{6}$ started with reducing 6bromonicotinaldehyde with sodium borohydride to the alcohol $\mathbf{6}$, followed by chlorination with 
thionyl chloride to form 7 (Figure 3). The bromo-styrylpyridine derivative with the required $E$ stereochemistry, 8, was prepared via a Horner-Wadsworth-Emmons reaction with 7, triethyl phosphite, sodium hydride and 4-(dimethylamino)benzaldehyde. Reacting the bromo-styrilpyridine, 8, with hydrazine yielded the substituted hydrazine 9 that was then reacted with either methylisothiocyante or $\mathrm{N}, \mathrm{N}$-dimethylaminoethylisothiocyanate to form the $\mathrm{H}_{2} \mathbf{L}^{5}$ and $\mathrm{H}_{2} \mathbf{L}^{6}$ respectively.

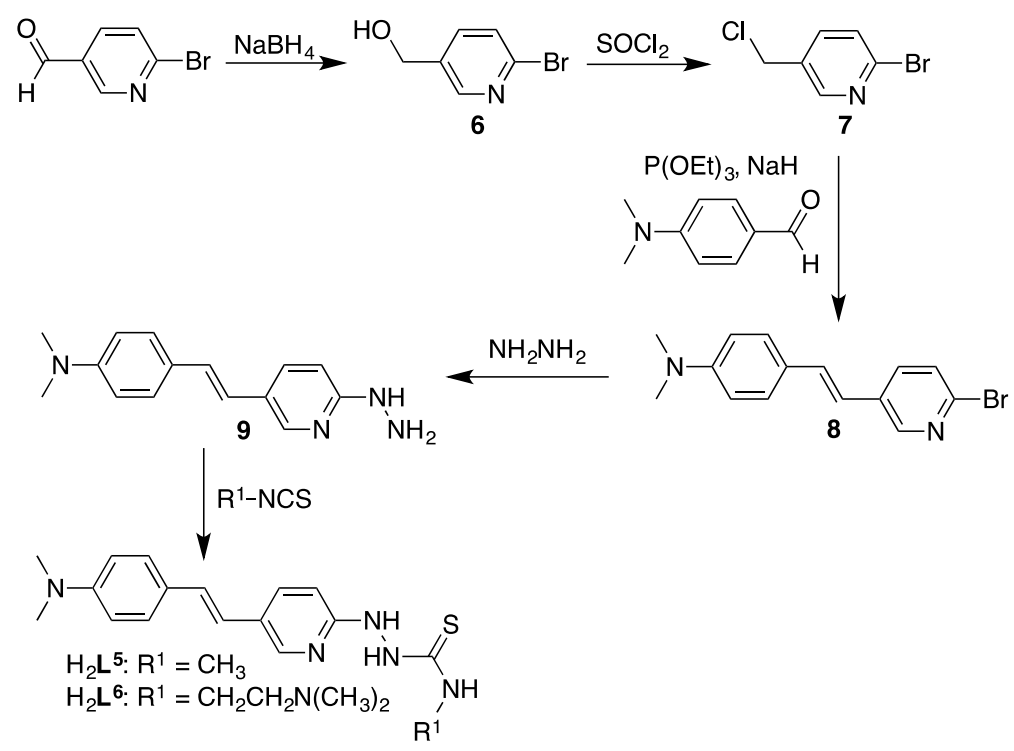

Figure 3. Synthetic route of styrilpyridyl derivatives $\mathrm{H}_{2} \mathbf{L}^{5-6}$.

Dark red rhenium-oxo complexes, $\left[\mathrm{ReO}\left(\mathrm{HL}^{1-6}\right)_{2}\right]^{+}$, can be prepared by reacting the ligands with trans-[ReOCl$\left.{ }_{3}\left(\mathrm{PPh}_{3}\right)_{2}\right]$ in methanol. The IR spectra of the $\left[\mathrm{ReO}\left(\mathrm{H}_{2} \mathbf{L}^{1-5}\right)_{2}\right]^{+}$, display the expected signals at $v=955-969 \mathrm{~cm}^{-1}$ due to the presence of the Re-oxo core. The electrospray ionisation mass spectra of each of the complexes revealed signals for $\left[\mathrm{ReO}\left(\mathrm{HL}^{1-6}\right)_{2}\right]^{+}$with the expected isotope patterns. The mass spectra the complexes with a terminal dimethylaminoethane functional group, $\left[\mathrm{ReO}\left(\mathrm{HL}^{2}\right)_{2}\right]^{+},\left[\mathrm{ReO}\left(\mathrm{HL}^{4}\right)_{2}\right]^{+}$and $\left[\mathrm{ReO}\left(\mathrm{HL}^{6}\right)_{2}\right]^{+}$also had signals that could be attributed to di- and trications, presumably due to protonation of the tertiary amine.

Each of the six complexes give clear well-resolved ${ }^{1} \mathrm{H}$ NMR spectra consistent with a diamagnetic ground state. The two coordinated ligands are magnetically equivalent. Coordination to the Re-oxo core results in a general trend for a downfield shift in the chemical shift of the resonances attributed to the aromatic protons when compared to the free ligands. 

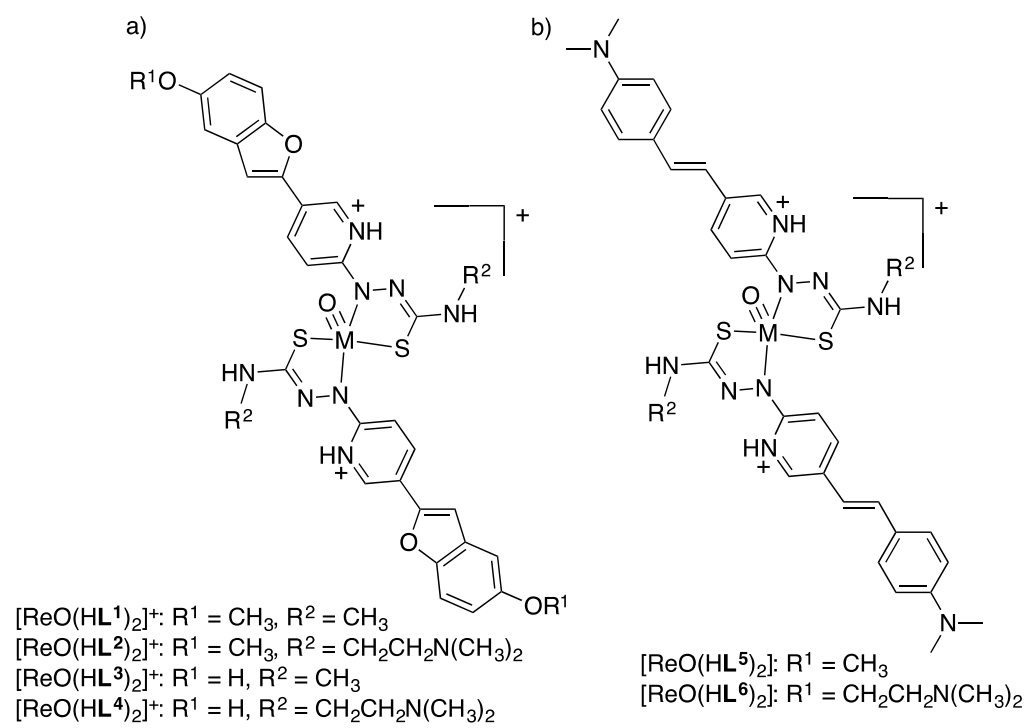

Figure 4. Chemical structures of $\left[\mathrm{ReO}\left(\mathrm{HL}^{1-6}\right)_{2}\right]^{+}$.

Crystals of $\left[\mathrm{ReO}\left(\mathbf{L}^{4}\right)_{2}\right]^{3+}$ marginally suitable for analysis by X-ray crystallography were isolated by vapour diffusion of diethyl ether to a mixture of $\left[\mathrm{ReO}\left(\mathrm{HL}^{4}\right)_{2}\right]^{+}$dissolved in dimethylformamide that had been acidified by addition of $\mathrm{HBF}_{4}$. Addition of the acid to aid crystallisation resulted in protonation of both the pyridyl and dimethylamine functional groups but the coordinated thiosemicarbazide fragment still serves as a dianionic ligand resulting in an overall charge neutral zwitterionic ligand (Figure 5a). The C3-N3 bond distance, 1.302(1) $\AA$, is relatively short suggesting significant $\mathrm{sp}^{2}$ hybridisation and $\mathrm{C}=\mathrm{N}$ character and the $\mathrm{C} 3-\mathrm{S} 1$ bond distance $(1.757(9) \AA)$ is consistent with thiol-like rather than thione character. The complex lies on a crystallographic 2-fold axis of symmetry through the Re-O1 bond. The protonated pyridyl nitrogen forms a N-H...F hydrogen bond to the $\mathrm{BF}_{4}^{-}$counterion (N5...F4 2.79(1) $\AA$, N4-H4...F4 147 ) while the protonated dimethylamino nitrogen $\mathrm{N} 1$ forms a N-H...O hydrogen to a molecule of DMF ( N1 ...O4 2.77(1) A, $\left.\mathrm{N} 1-\mathrm{H} 1 \ldots \mathrm{O} 4151^{\circ}\right)\left(\right.$ Figure $5 \mathrm{~b}$ ). The structure contained two ordered $\mathrm{BF}_{4}^{-}$counterions which are hydrogen bonded to the complex but a third $\mathrm{BF}_{4}^{-}$counterion and several DMF solvent molecules were extensively disordered. A sensible model for the disordered $\mathrm{BF}_{4}{ }_{4}^{-}$could not be recognised from the difference electron density so this disordered counterion and the disordered solvent were removed using the Squeeze procedure.[37] The benzofuran functional group was disordered over two orientations related by a $180^{\circ}$ rotation about the $\mathrm{C} 8-\mathrm{C} 10$ bond with occupancies close to 50:50.

The rhenium ion is in a distorted square pyramidal environment with the dianionic thiosemicarbazide fragment forming a N,N/S,S trans configuration about the Re-oxo consistent with two other rhenium-oxo pyridylthiocarbazide complexes characterised in our earlier work.[35, 36] The selective formation of the N,N/S,S trans geometric isomer is presumably due to a "trans 
effect", although steric requirements may also play some role.[38-40] The Re-O1 bond distance (1.625(1 $\AA)$ is relatively short even for rhenium(V)-oxo bonds.[41-43] The Re-N4 bond length, $2.058(7) \AA$ is shorter than typical $\mathrm{Re}-\mathrm{N}$ bonds $(\mathrm{ca} \quad-\quad \AA$ ) suggesting some degree of multiple bond character.[40, 42, 43] The Re-S bond distance 2.281(2) $\AA$ is similar to the $\operatorname{Re}-\mathrm{S}$ bond distances in rhenium(V) complexes with amino thiolate ligands and $\mathrm{Re}-\mathrm{S}$ bond distances in rhenium complexes with thiosemicarbazonato ligands.[40, 44, 45]

Crystals of the formally charge neutral complex, $\left[\mathrm{ReO}\left(\mathrm{HL}^{6}\right)\left(\mathbf{L}^{6}\right)\right]$, were isolated from the filtrate of the reaction mixture and were characterised by X-ray crystallography (Figure $5 \mathrm{c}$ ). In this instance the thiosemicarbazide fragment of each bidentate ligand still serves as a formal dianionic bidentate ligands. The pyridyl functional groups are not protonated but one of the ligands has a protonated dimethylamino group, that is involved in an intramolecular hydrogen bond to the pyridyl functional group present on the same ligand, to give an overall charge neutral complex. The N3C16 (1.265(1) $\AA$ ) and N9-C37 (1.312(1) Å) bonds are shorter than the other C-N bonds suggesting significant double bond character. Once again, the rhenium ion is in a distorted square pyramidal environment with the dianionic thiosemicarbazide fragment binding in a N,N/S,S trans configuration about the Re-oxo. The Re-O1 bond (1.695(9) $\AA$ ) is within the expected range.[41] The Re-N (average $2.016 \AA$ ) and Re-S bonds (average $2.290 \AA$ ) are similar to those found in $\left[\mathrm{ReO}\left(\mathrm{L}^{4}\right)_{2}\right]$ and two other rhenium-oxo pyridylthiocarbazide complexes characterised in our earlier work.[35, 36]

a)

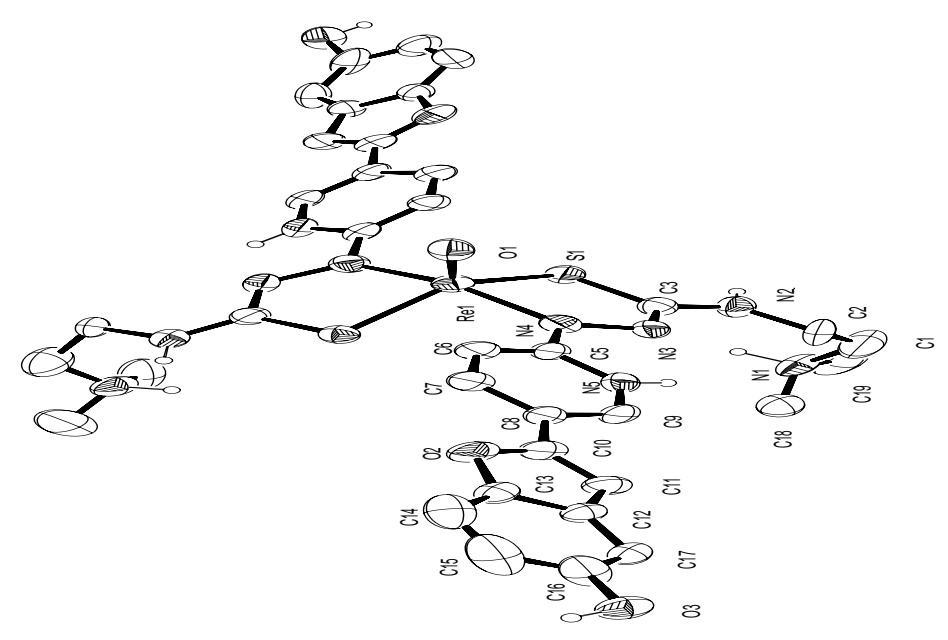


b)

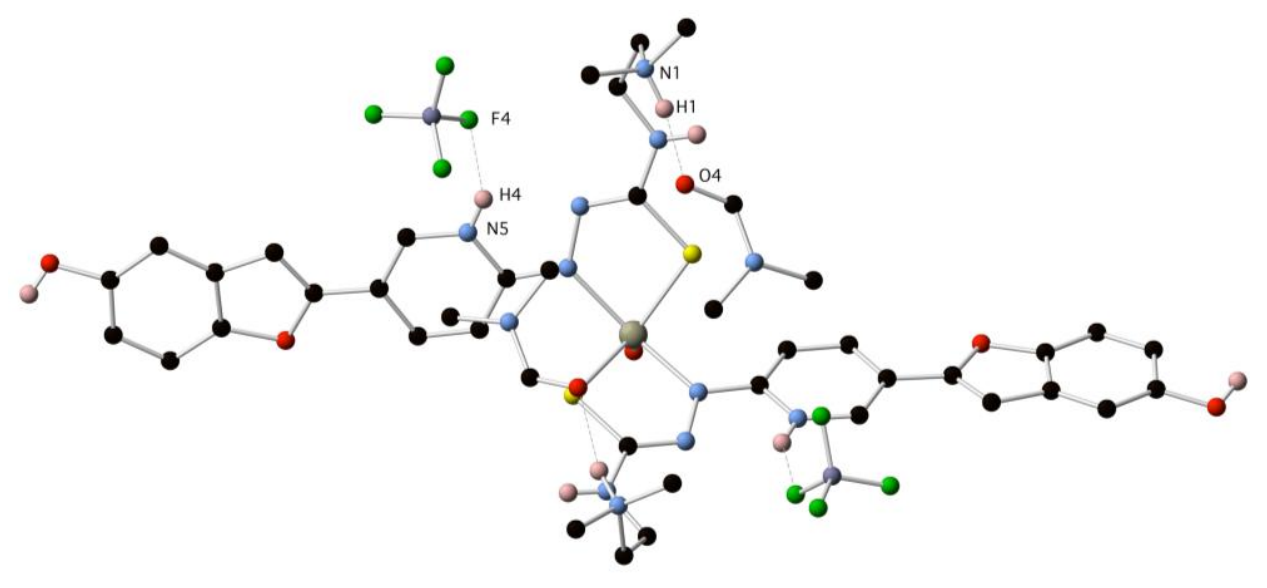

c)

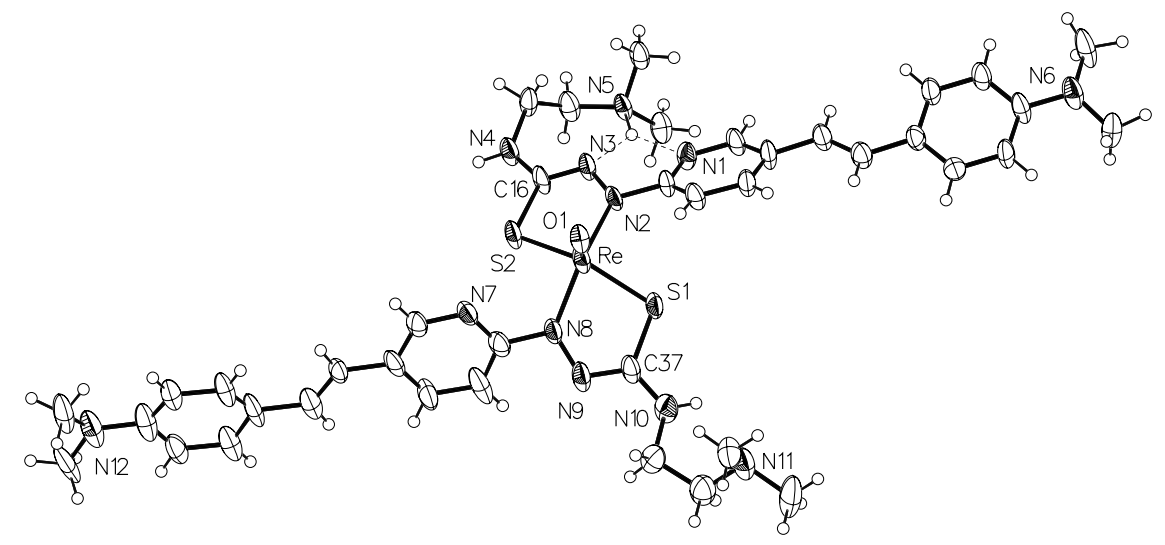

Figure 5. a) ORTEP representation of the cation present in $\left[\mathrm{ReO}\left(\mathrm{H}_{2} \mathbf{L}^{4}\right)_{2}\right]\left(\mathrm{BF}_{4}\right)_{3}$.2DMF. Ellipsoids are at the $30 \%$ level. Anions and solvent removed for clarity. b) Hydrogen bonding interactions present in $\left[\mathrm{ReO}\left(\mathrm{L}^{4}\right)_{2}\right]\left(\mathrm{BF}_{4}\right)_{3} .2 \mathrm{DMF}$. The protonated pyridine nitrogen forms a N-H...F hydrogen

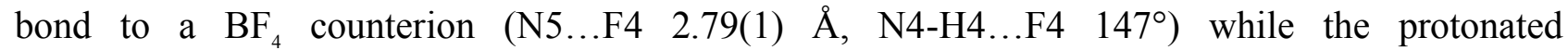
dimethylamino nitrogen $\mathrm{N} 1$ forms a N-H...O hydrogen to a molecule of DMF ( N1...O4 2.77(1) Å, $\left.\mathrm{N} 1-\mathrm{H} 1 \ldots \mathrm{O} 4151^{\circ}\right)$. c) ORTEP representation of $\left[\mathrm{ReO}\left(\mathrm{HL}^{6}\right)\left(\mathbf{L}^{6}\right)\right]$.

Interaction of $\left[\operatorname{ReO}\left(\mathrm{L}^{1-6}\right)_{2}\right]^{+}$with Amyloid- ${ }_{1-42}$ and Amyloid Plaques present in Human Brain Tissue

The interaction of the rhenium complexes, $\left[\mathrm{ReO}\left(\mathrm{HL}^{1-6}\right)_{2}\right]^{+}$with synthetic $\mathrm{A}_{1-42}$ was investigated using the fluorescent probe thioflavin-T (ThT, (2-[p-(dimethylamino)phenyl]-3,6-dimethylbenzothiaolium chloride). The fluorescence of ThT undergoes a $115 \mathrm{~nm}$ red shift in its excitation profile on binding to A fibrils leading to fluorescence emission at ${ }_{\mathrm{em}}=485 \mathrm{~nm}$ following excitation at ${ }_{\mathrm{ex}}=440 \mathrm{~nm}$. Incubating $\mathrm{A}_{1-42}(10 \mathrm{M})$ in phosphate buffered saline at $37{ }^{\circ} \mathrm{C}$ leads to the formation 
of A fibrils with the emission from ThT reaching a maximum value after about 13 hours (Figure 6). Addition of $\left[\mathrm{ReO}\left(\mathrm{HL}^{1}\right)_{2}\right]^{+}\left(\begin{array}{ll}20 & \mathrm{M}\end{array}\right)$ to a mixture of $\mathrm{A}_{1-42}$ only resulted in a modest reduction in fluorescence suggesting this complex has little interaction with $\mathrm{A}_{1-42}$. In comparison, addition of each of the other five rhenium complexes resulted in significant reductions in fluorescence suggesting that these complexes either bind competitively with ThT to $\mathrm{A}_{142}$ fibrils or inhibit fibril formation. The most significant reductions in fluorescence were seen following addition of $\left[\mathrm{ReO}\left(\mathrm{HL}^{2}\right)_{2}\right]^{+},\left[\mathrm{ReO}\left(\mathrm{HL}^{6}\right)_{2}\right]^{+}$and $\left[\mathrm{ReO}\left(\mathrm{HL}^{4}\right)_{2}\right]^{+}$

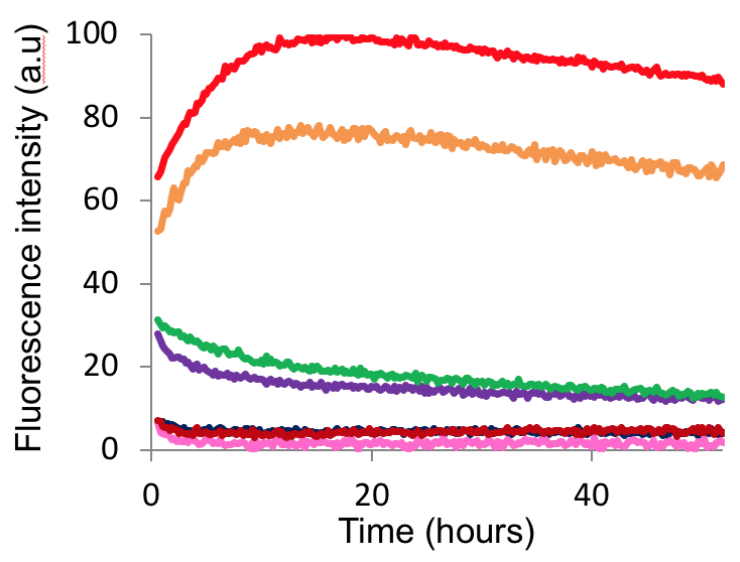

Figure 6. Time dependent changes in ThT fluorescence $\left(_{\text {ex }}=440 \mathrm{~nm},_{\mathrm{em}}=480 \mathrm{mn}\right)$ over $52 \mathrm{~h}$ for solutions of ThT $(40 \mu \mathrm{M})$ and freshly prepared $\mathrm{A}_{1-42}(10 \mu \mathrm{M})$ at $37^{\circ} \mathrm{C}$ (red). Following addition of $\left[\mathrm{ReO}\left(\mathrm{HL}^{1}\right)_{2}\right]^{+}(20 \mu \mathrm{M})$ orange; $\left[\mathrm{ReO}\left(\mathrm{HL}^{5}\right)_{2}\right]^{+}$(green); $\left[\mathrm{ReO}\left(\mathrm{HL}^{3}\right)_{2}\right]^{+}$(purple); $\left[\mathrm{ReO}\left(\mathrm{HL}^{6}\right)_{2}\right]^{+}$(red); $\left[\mathrm{ReO}\left(\mathrm{HL}^{2}\right)_{2}\right]^{+}$(black); $\left[\mathrm{ReO}\left(\mathrm{HL}^{4}\right)_{2}\right]^{+}$(pink).

The styrilpyridyl functional group present in $\left[\mathrm{ReO}\left(\mathrm{HL}^{5}\right)_{2}\right]^{+}$and $\left[\mathrm{ReO}\left(\mathrm{HL}^{6}\right)_{2}\right]^{+}$contributes to the complexes being fluorescent $\left(\lambda_{\mathrm{em}}=460 \mathrm{~nm}, \lambda_{\mathrm{ex}}=370 \mathrm{~nm}\right)$ and this fluoresence can be used to detect the complexes in human brain tissue using epi-fluorescent microscopy. Serial sections $(7 \mu \mathrm{m})$ of post-mortem samples of frontal cortex of human brain tissue from clinically diagnosed Alzheimer's Disease subjects were pretreated with bovine serum albumin to prevent nonselective binding and then treated with $\left[\mathrm{ReO}\left(\mathrm{HL}^{6}\right)_{2}\right]^{+}(10 \mu \mathrm{M}$ in $15 \% \mathrm{DMSO} /$ phosphate buffered solution (PBS), $10 \mathrm{~min})$. The localization of $\left[\mathrm{ReO}\left(\mathrm{HL}^{6}\right)_{2}\right]^{+}$on the treated brain tissue was measured by epi-fluorescent microscopy $\left(\lambda_{\mathrm{ex}}=405 \mathrm{~nm}, \lambda_{\mathrm{em}}=461 \mathrm{~nm}\right.$, Figure $7 \mathrm{~b}$ ) and comparison with the contiguous section immuno-stained with an $A \beta$ antibody (1E8), Figure 7a, to identify plaques reveals good colocalisation and binding to A plaques. Amyloid- $\beta$ plaques are typically $40-60 \mu \mathrm{m}$ in diameter so sequential $7 \mu \mathrm{m}$ serial tissue sections often, but not always, contain portions of the same plaque. The complex was not retained in a healthy age-matched control tissue (Figure $7 \mathrm{c}$ and $7 \mathrm{~d}$ ). The 
complexes with a benzofuran functional group are not sufficiently fluorescent to permit their detection on brain tissue.
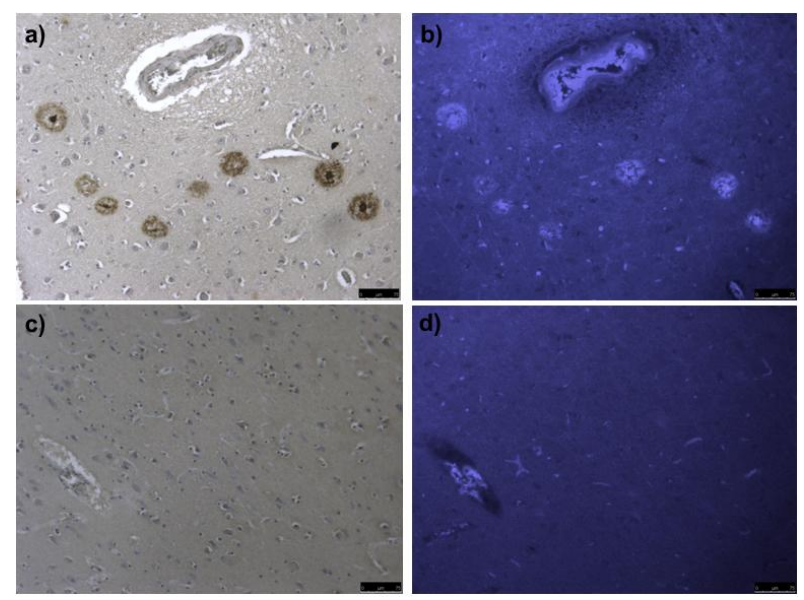

Figure 7. Images a) is human brain tissue from an AD patients b) from aged matched healthy control, both stained with 1E8 antibody and visualised with bright field microscopy. Images b) and d) are the contiguous sections of these tissues respectively and are stained with $\left[\mathrm{ReO}\left(\mathrm{H}_{2} \mathbf{L}^{6}\right)_{2}\right] \mathrm{Cl}$ and were visualised by epifluorescence, $\left(\lambda_{\mathrm{ex}}=405 \mathrm{~nm}, \lambda_{\mathrm{em}}=461 \mathrm{~nm}\right)$ microscopy. Scale bar $=75 \mathrm{M}$.

\section{Synthesis of $\left[{ }^{99 \mathrm{~m}} \mathrm{TcO}\left(\mathrm{HL}^{5-6}\right)_{2}\right]^{+}$}

The fact that the styrylpyridyl complex $\left[\mathrm{ReO}\left(\mathrm{HL}^{6}\right)_{2}\right]^{+}$revealed strong interactions in the $\mathrm{A}_{1-42}$ fibril assay and bound to A plaques in human brain tissue encouraged us to investigate the potential to prepare the technetium-99m analogues. $\left[{ }^{99 \mathrm{~m}} \mathrm{TcO}\left(\mathrm{HL}^{5}\right)_{2}\right]^{+}$and $\left[{ }^{99 \mathrm{~m}} \mathrm{TcO}\left(\mathrm{HL}^{6}\right)_{2}\right]^{+}$were prepared by adding aqueous $\left[{ }^{99 \mathrm{~m}} \mathrm{TcO}_{4}\right]^{-}(1 \mathrm{~mL}$ in $0.9 \%$ saline, $\sim 1000 \mathrm{MBq})$ to a mixture of the ligands in ethanol $\left(1 \mathrm{mg} \mathrm{mL} L^{-1}\right)$ in the presence of tin chloride $\left(1 \mathrm{mg} \mathrm{mL}^{-1}\right)$ to serve as a reducing agent. The mixtures were left at room temperature for 30 minutes then analysed by reversed phase HPLC with radioactivity detection (Figure 8). The HPLC analysis revealed the little 'free' [ $\left.{ }^{99 \mathrm{~m}} \mathrm{TcO} 4\right]$ ', as using this mobile phase, the anion elutes as a broad peak with the solvent front ( $c a .2$ minutes). For both reactions a single major radioactive peak was evident that had a similar retention time to the nonradioactive rhenium-oxo complexes (detected $\lambda=254 \mathrm{~nm}$ ) suggesting that structurally analogous $\left[{ }^{99 \mathrm{~m}} \mathrm{TcO}\left(\mathrm{HL}^{5}\right)_{2}\right]^{+}$and $\left[{ }^{99 \mathrm{~m}} \mathrm{TcO}\left(\mathrm{HL}^{6}\right)_{2}\right]^{+}$complexes. The slight differences between the retention times of the radioactive peak ( ${ }^{99 \mathrm{~m}} \mathrm{Tc}$ complex) and UV peak (Re complex) in the HPLC chromatograms is partly due to the relative detector configuration but could also reflect the difference in polarity of the rhenium-oxo and technetium-oxo cores. 

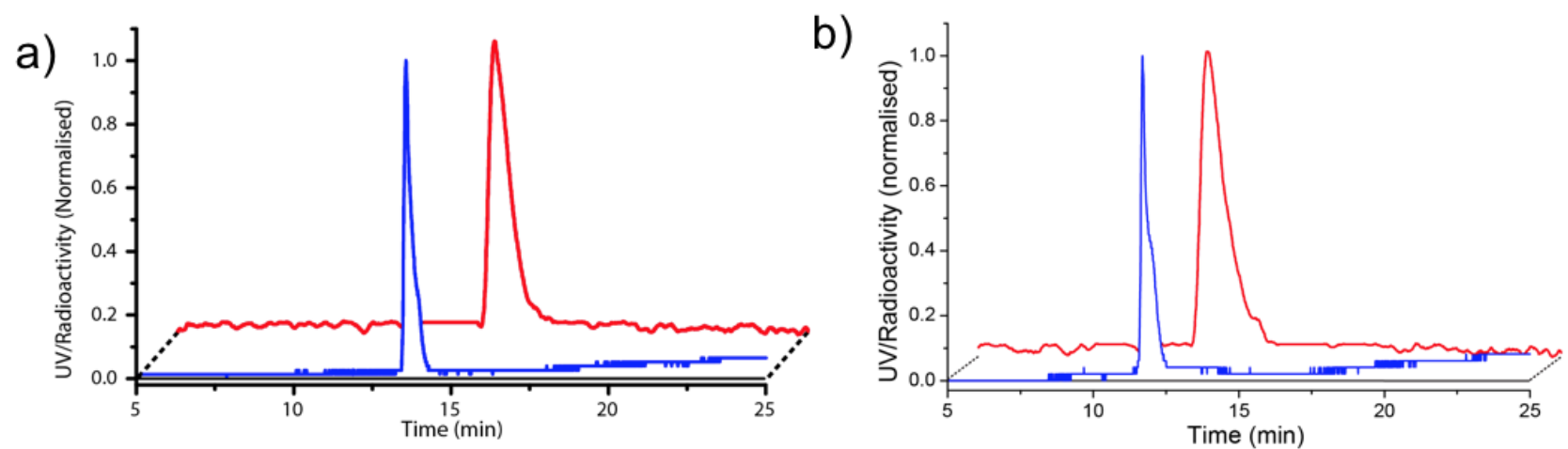

Figure 8. a) Reversed-phase HPLC chromatograms of $\left[\mathrm{ReO}\left(\mathrm{HL}^{5}\right)_{2}\right]^{+}$(blue, UV detection at $\lambda=254$ $\mathrm{nm}$ ) and $\left[{ }^{99 \mathrm{~m}} \mathrm{TcO}\left(\mathrm{HL}^{5}\right)_{2}\right]^{+}$(red, radiation detection). b) Reversed phase HPLC chromatograms of $\left[\mathrm{ReO}\left(\mathrm{HL}^{6}\right)_{2}\right]^{+}$(blue, UV detection at $\lambda=254 \mathrm{~nm}$ ) and $\left[{ }^{99 \mathrm{~m}} \mathrm{TcO}\left(\mathrm{HL}^{6}\right)_{2}\right]^{+}$(red, radioation detection).

\section{Concluding Remarks}

Six new substituted pyridylthiosemicarbazide ligands containing either benzofuran or styrylpyridyl functional groups that are known to selectively bind to amyloid plaques were prepared. The new ligands were used to prepare well defined [Re-oxo $]^{3+}$ complexes where two substituted pyridylthiosemicarbazide ligands were coordinated to a single metal ion to give bivalent complexes with two amyloid- targeting functional groups. Each of the complexes were analysed by NMR spectroscopy and mass spectrometry. Two rhenium complexes were characterized by X-ray crystallography confirming the rhenium(V) was in a square pyramidal geometry with an apical oxygen ligand and each thiosemicarbazide ligand acting as a dianionic bidentate ligand selectively forming the N,N/S,S trans geometric isomer. The interaction of the complexes with synthetic $\mathrm{A}_{1-42}$ was investigated using ThT as a fluorescent probe for amyloid fibrils. Five of the new complexes either bind competitively with $\mathrm{ThT}$ to $\mathrm{A}_{1-42}$ fibrils or inhibit fibril formation. One of the styrylpyridyl containing complexes, $\left[\operatorname{ReO}\left(\mathrm{H}_{2} \mathbf{L}^{6}\right)_{2}\right] \mathrm{Cl}$, was selected and shown to bind to amyloid plaques present in post-mortem human brain tissue. Preliminary radiolabelling experiments suggested it was relatively simple to prepare $\left[{ }^{99 \mathrm{~m}} \mathrm{TcO}\left(\mathrm{HL}^{5}\right)_{2}\right]^{+}$and $\left[{ }^{99 \mathrm{~m}} \mathrm{TcO}\left(\mathrm{HL}^{6}\right)_{2}\right]^{+}$in $\operatorname{good}$ radiochemical yields. The complexes reported here may warrant further studies to further investigate their potential to be of use in assisting in the diagnosis of cerebral amyloid angiopathy.

\section{Experimental}

\section{Materials and Reagents}

All reagents and solvents were obtained from standard commercial sources and used without further purification. The isotope ${ }^{99 \mathrm{~m}} \mathrm{Tc}$ was received as pertechnetate eluted from a technetium- $99 \mathrm{~m}$ 
generator as $\left[{ }^{99 \mathrm{~m}} \mathrm{TcO}_{4}\right]^{-}$in a saline solution. Compounds $\mathbf{1}[16], 6$ and 7-10[46]were prepared according to reported procedures.

\section{Instrumentation}

${ }^{1} \mathrm{H},{ }^{13} \mathrm{C}$, COSY, HSQC, HMBC spectra were all recorded using a Varian FT-NMR 400 or Varian FT-NMR 500 spectrometer (Varian, California USA). All ${ }^{1} \mathrm{H}$ NMR spectra were acquired at 400 $\mathrm{MHz}$ or $500 \mathrm{MHz}$ and ${ }^{13} \mathrm{C}$ spectra were acquired at $101 \mathrm{MHz}$ and $126 \mathrm{MHz}$. The reported peaks were all referenced to solvent peaks in the order of parts per million at $25^{\circ} \mathrm{C}$. ESI-MS - All ESI-MS data were recorded on an Agilent 6510 ESI-TOF LC/MS Mass Spectrometer (Agilent, California USA). Absorbance spectra were recorded using a Shimadzu UV-1650 PC spectrophotometer (Shimadzu, Sydney NSW). Emission spectra were recorded on a Varian CAREY Eclipse fluorescence spectrophotometer (Varian, California USA). Infrared spectra were obtained from a Perkin Elmer Spectrum One FTIR spectrometer (Waltham, Massachusetts USA).

Non-radioactive analytical HPLC were performed on an agilent 1100 Series. Samples were analysed using Column 1: an SGE ProteCol ${ }^{\mathrm{TM}}$ c18 HPH 125 column (4.6 x 150 mm, $5 \mu \mathrm{m}, 120 \AA$ ). Gradient elution followed System A: gradient elution of Buffer A $\left(0.1 \%\right.$ TFA in $\left.\mathrm{H}_{2} \mathrm{O}\right)$ and Buffer B $\left(0.1 \%\right.$ TFA in $\left.\mathrm{CH}_{3} \mathrm{CN}\right)$ from 0 to $100 \% \mathrm{~B}$ to $\mathrm{A}$ over $20 \mathrm{~min}$ and $\mathrm{UV}$ detection at $\lambda=254 \mathrm{~nm}$. Analytical HPLC traces of radiolabelled compounds were acquired using a Shmadzu 10 AVP UVvisible spectrophotometer (Shimadzi, Kyoto Japan) and a sodium iodide scintillation detector with two LC-10ATVP solvent delivery systems for solvent A and B. Peak separation was achieved using Column 2: Nacalai Tesque Cosomosil 5C18-AR Waters column $(4.6$ x $150 \mathrm{~mm}, 5 \mu \mathrm{m})($ Kyoto,

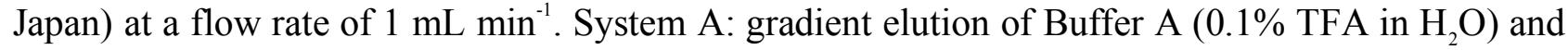
Buffer $\mathrm{B}\left(0.1 \%\right.$ TFA in $\left.\mathrm{CH}_{3} \mathrm{CN}\right)$ from 0 to $100 \% \mathrm{~B}$ to $\mathrm{A}$ over $20 \mathrm{~min}$ and $\mathrm{UV}$ detection at $\lambda=254$ nm. 


\section{Syntheses of Benzofuran and Styrylpyridyl Derivative Ligands}

\section{2-chloro-5-(5-methoxybenzofuran-2-yl)pyridine (2)}

A mixture of 5-methoxy-2-benzofuranyl-boronic acid (474 mg, $2.47 \mathrm{mmol}$ ), 2-chloro-5iodopyridine (562 mg, $2.35 \mathrm{mmol}$ ), palladium(II)-bis(triphenylphosphine)dichloride (52.0 mg, $0.074 \mathrm{mmol})$ and potassium carbonate $(682 \mathrm{mg}, 4.94 \mathrm{mmol})$ were heated at reflux in ethanol (17 $\mathrm{mL}$ ) for $4 \mathrm{~h}$ under an atmosphere of dinitrogen. The solvent was then removed in vacuo and the product was extracted from a brine solution with ethyl acetate. The organic layer was dried with $\mathrm{MgSO}_{4}$ and the ethyl acetate was removed in vacuo. The crude product was purified by flash chromatography (DCM). DCM was removed under vacuum producing a beige-yellow solid which was collected and dried at $50^{\circ} \mathrm{C}$ in vacuo for $4 \mathrm{~h}(554 \mathrm{mg}, 91 \%) .{ }^{1} \mathrm{H}$ NMR $\left[\mathrm{CDCl}_{3}, 400 \mathrm{MHz}\right]$ : $\delta$ (ppm) $8.84(\mathrm{~d}, \mathrm{~J}=2.4 \mathrm{~Hz}, 1 \mathrm{H}), 8.05(\mathrm{dd}, \mathrm{J}=8.3,2.5 \mathrm{~Hz}, 1 \mathrm{H}), 7.42$ (d, J = 9.4 Hz, 1H), 7.39 (s, 1H), $7.051(\mathrm{~s}, 1 \mathrm{H}), 7.046(\mathrm{~s}, 1 \mathrm{H}), 6.94(\mathrm{dd}, \mathrm{J}=8.9,2.6 \mathrm{~Hz}, 1 \mathrm{H}), 3.86(\mathrm{~s}, 3 \mathrm{H}) .{ }^{13} \mathrm{C}\left\{{ }^{1} \mathrm{H}\right\} \mathrm{NMR}\left[\mathrm{CDCl}_{3}, 101\right.$ MHz]: $\delta(p p m) 156.5,152.6,150.9,150.3,146.2$, 134.6, 129.3, 125.8, 124.5, 114.3, 112.0, 103.6, 56.1. ESI-MS (+ve ion): $\mathrm{m} / z 259.9567$ (experimental), 260.0478 (calculated for $\left[\mathrm{C}_{14} \mathrm{H}_{11} \mathrm{ClNO}_{2}\right]^{\dagger}$ ).

\section{2-(6-chloropyridin-3-yl)benzofuran-5-ol (3)}

2-(6-chloro-3-pyridinyl)-5-methoxybenzofuran (300 mg, $1.16 \mathrm{mmol})$ was dissolved in DCM (5 mL). To this mixture, boron tribromide in DCM $(1 \mathrm{M}, 2.0 \mathrm{~mL}, 2.00 \mathrm{mmol})$ was added dropwise at $0^{\circ} \mathrm{C}$ under an atmosphere of dinitrogen. The reaction was allowed to reach room temperature and stirred for a further $4 \mathrm{~h}$. An off-white-brown precipitate was observed before $\mathrm{H}_{2} \mathrm{O}(20 \mathrm{~mL})$ was added slowly, followed by the slow addition of $\mathrm{NaHCO}_{3}(20 \mathrm{~mL}$, sat. aq.). The solid was collected by filtration, washed with $\mathrm{H}_{2} \mathrm{O}(10 \mathrm{~mL})$, cold ethanol $(1-2 \mathrm{~mL})$ and pentane $(2 \times 10 \mathrm{~mL})$. The brown solid was dissolved in ethyl acetate $(30 \mathrm{~mL})$ and was taken to dryness in vacuo to afford a brown powder. (228 mg, 80\%). ${ }^{1} \mathrm{H}$ NMR [CD $\left.\mathrm{OD}, 400 \mathrm{MHz}\right]: \delta(\mathrm{ppm}) 8.84(\mathrm{~d}, \mathrm{~J}=2.5 \mathrm{~Hz}, 1 \mathrm{H}, 11), 8.22$ $(\mathrm{dd}, \mathrm{J}=8.4,2.5 \mathrm{~Hz}, 1 \mathrm{H}, 12), 7.52(\mathrm{~d}, \mathrm{~J}=8.4 \mathrm{~Hz}, 1 \mathrm{H}, 13), 7.35$ (d, J = 8.8 Hz, 1H, 4), 7.23 (s, 1H, 8), $6.98(\mathrm{~d}, \mathrm{~J}=2.5 \mathrm{~Hz}, 1 \mathrm{H}, 7), 6.82(\mathrm{dd}, \mathrm{J}=8.9,2.5 \mathrm{~Hz}, 1 \mathrm{H}, 3) .{ }^{13} \mathrm{C}\left\{{ }^{1} \mathrm{H}\right\} \mathrm{NMR}\left[\mathrm{CD}_{3} \mathrm{OD}, 101 \mathrm{MHz}\right]: \delta$ (ppm) 155.0, 153.4 , 151.4, 151.1, 146.6, 136.3, 130.9, 127.6, 125.8, 115.4, 112.4, 106.8, 104.9. ESI-MS (+ve ion): $m / z 246.0343$ (experimental), 246.0322 (calculated for $\left[\mathrm{C}_{13} \mathrm{H}_{9} \mathrm{ClNO}_{2}\right]^{\dagger}$ ).

\section{2-hydrazinyl-5-(5-methoxybenzofuran-2-yl)pyridine (4)}

To a flask charged with 2-(6-chloro-3-pyridinyl)-5-methoxybenzofuran (300 mg, $1.16 \mathrm{mmol}$ ), hydrazine hydrate $(5 \mathrm{~mL}, 30 \%, 48.3 \mathrm{mmol})$ was added dropwise at $0^{\circ} \mathrm{C}$. The mixture was heated at reflux overnight and cooled to $0{ }^{\circ} \mathrm{C}$ leading to the formation of colourless precipitate. The precipitate was collected by filtration and washed with $\mathrm{H}_{2} \mathrm{O}(10 \mathrm{~mL})$, cold ethanol $(1-2 \mathrm{~mL})$, diethyl ether $(2 \times 10 \mathrm{~mL})$ and pentane $(2 \times 10 \mathrm{~mL})$. The solid was dried at $50^{\circ} \mathrm{C}$ in vacuo for $4 \mathrm{~h}$ to afford a colourless powder (275 mg, 93\%). ${ }^{1} \mathrm{H}$ NMR [DMSO-d 6 , $\left.400 \mathrm{MHz}\right]: \delta(\mathrm{ppm}) 8.52(\mathrm{~d}, \mathrm{~J}=2.3 \mathrm{~Hz}, 1 \mathrm{H})$, $7.91(\mathrm{dd}, \mathrm{J}=8.8,2.4 \mathrm{~Hz}, 1 \mathrm{H}), 7.89$ (s, 1H), 7.45 (d, J = 8.9 Hz, 1H), 7.08 (d, J = 2.6 Hz, 1H), 7.07 (s, 1H), 6.83-6.80 (m, 2H), 4.27 (s, 2H), $3.78(\mathrm{~s}, 3 \mathrm{H}) .{ }^{13} \mathrm{C}\left\{{ }^{1} \mathrm{H}\right\}$ NMR [DMSO-d, $\left.101 \mathrm{MHz}\right]: \delta(\mathrm{ppm})$ 
$161.7,155.7,155.3,148.7,144.4,133.4,129.8,114.9,111.8,111.2,106.0,103.1,99.0$, 55.5. ESIMS (+ve ion): $m / z 256.1060$ (experimental), 256.1086 (calculated for $\left[\mathrm{C}_{14} \mathrm{H}_{14} \mathrm{~N}_{3} \mathrm{O}_{2}\right]^{+}$)

\section{2-(6-hydrazinylpyridin-3-yl)benzofuran-5-ol (5)}

To a flask charged with 2-(6-chloro-3-pyridinyl)-5-benzofuranol (200 mg, $0.814 \mathrm{mmol})$, hydrazine hydrate $(6 \mathrm{~mL}, 30 \%, 57 \mathrm{mmol})$ was added dropwise at $0^{\circ} \mathrm{C}$. The mixture was heated at reflux overnight and then cooled to to $0^{\circ} \mathrm{C}$. The off-white precipitate was collected by filtration and washed with $\mathrm{H}_{2} \mathrm{O}(10 \mathrm{~mL})$, cold ethanol (1-2 mL), diethyl ether $(2 \times 10 \mathrm{~mL})$ and pentane $(2 \times 10$ $\mathrm{mL})$. The solid was dried at $50^{\circ} \mathrm{C}$ in vacuo for $4 \mathrm{~h}$ to afford a colourless powder $(185 \mathrm{mg}, 95 \%)$. ${ }^{1} \mathrm{H}$ NMR [DMSO-d, 400 MHz]: $\delta(\mathrm{ppm}) 9.13(\mathrm{~s}, 1 \mathrm{H}), 8.49$ (d, J = 2.2 Hz, 1H), 7.88 (dd, J = 8.9, 2.4 $\mathrm{Hz}, 1 \mathrm{H}), 7.86(\mathrm{~s}, 1 \mathrm{H}), 7.33(\mathrm{~d}, \mathrm{~J}=8.7 \mathrm{~Hz}, 1 \mathrm{H}), 6.99(\mathrm{~s}, 1 \mathrm{H}), 6.87$ (d, J = 2.4 Hz, 1H), 6.80 (d, J = $8.8 \mathrm{~Hz}, 1 \mathrm{H}), 6.67(\mathrm{dd}, \mathrm{J}=8.7,2.5 \mathrm{~Hz}, 1 \mathrm{H}), 4.24(\mathrm{~s}, 2 \mathrm{H}) .{ }^{13} \mathrm{C}\left\{{ }^{1} \mathrm{H}\right\}$ NMR [DMSO-d, $\left.101 \mathrm{MHz}\right]: \delta$ (ppm) 161.6, 154.9, 153.4, 148.0, 144.3, 133.3, 129.9, 115.1, 112.1, 110.9, 106.0, 104.9, 98.8. ESIMS (+ve ion): $m / z 242.1100$ (experimental), 242.0930 (calculated for $\left[\mathrm{C}_{13} \mathrm{H}_{12} \mathrm{~N}_{3} \mathrm{O}_{2}\right]^{+}$)

$H_{2} \boldsymbol{L}^{1}$

A mixture of 2-(6-hydrazinyl-3-pyridinyl)-5-methoxybenzofuran (80 $\mathrm{mg}, 0.313 \mathrm{mmol})$ and methyl isothiocyanate $(46 \mathrm{mg}, 0.63 \mathrm{mmol})$ were heated at reflux in ethanol $(4 \mathrm{~mL})$ for $4 \mathrm{~h}$. A colourless precipitate was observed and collected by filtration. The product was washed with diethyl ether $(2 \mathrm{x}$ $5 \mathrm{~mL})$ followed by pentane $(2 \times 5 \mathrm{~mL})$. The solid was dried at $50{ }^{\circ} \mathrm{C}$ in vacuo for $4 \mathrm{~h}$ to afford a colourless powder $(84 \mathrm{mg}, 82 \%) .{ }^{1} \mathrm{H}$ NMR [DMSO-d $\left.6,400 \mathrm{MHz}\right]: \delta(\mathrm{ppm}) 9.41(\mathrm{~s}, 1 \mathrm{H}), 8.75$ (s, $1 \mathrm{H}), 8.65(\mathrm{~d}, \mathrm{~J}=1.9 \mathrm{~Hz}, 1 \mathrm{H}), 8.16(\mathrm{~s}, 1 \mathrm{H}), 8.07(\mathrm{dd}, \mathrm{J}=8.6,2.1 \mathrm{~Hz}, 1 \mathrm{H}), 7.49(\mathrm{~d}, \mathrm{~J}=8.9 \mathrm{~Hz}, 1 \mathrm{H})$, 7.20 (s, 1H), $7.12(\mathrm{~d}, \mathrm{~J}=2.5 \mathrm{~Hz}, 1 \mathrm{H}), 6.86(\mathrm{dd}, \mathrm{J}=8.9,2.5 \mathrm{~Hz}, 1 \mathrm{H}), 6.63(\mathrm{~d}, \mathrm{~J}=8.7 \mathrm{~Hz}, 1 \mathrm{H}), 3.79$ $(\mathrm{s}, 3 \mathrm{H}), 2.88(\mathrm{~d}, \mathrm{~J}=4.4 \mathrm{~Hz}, 3 \mathrm{H}) ;{ }^{13} \mathrm{C}\left\{{ }^{1} \mathrm{H}\right\}$ NMR [DMSO-d, $\left.101 \mathrm{MHz}\right]: \delta(\mathrm{ppm}) 182.6,159.4,155.8$, $154.5,148.9$, 144.5, 134.1, 129.6, 117.9, 112.4, 111.4, 106.5, 103.3, 100.4, 55.6, 30.8; ESI-MS (+ve ion): $m / z 329.1073$ (experimental), 329.1072 (calculated for $\left[\mathrm{C}_{16} \mathrm{H}_{17} \mathrm{~N}_{4} \mathrm{O}_{2} \mathrm{~S}\right]^{\dagger}$ ). $\lambda_{\max }(\mathrm{DMSO}) \mathrm{nm}$ $\left(\varepsilon / \mathrm{dm}^{3} \mathrm{~mol}^{-1} \mathrm{~cm}^{-1}\right) 329$ (42268), 423 (29920). $\lambda_{\mathrm{ex}}=332 \mathrm{~nm}\left(\lambda_{\mathrm{em}}=400 \mathrm{~nm}\right)$. RP-HPLC (Column 2, System A): $\mathrm{R}_{\mathrm{T}}(\mathrm{min}) 10.3$. 
$H_{2} \boldsymbol{L}^{2}$

A mixture of 2-(6-hydrazinyl-3-pyridinyl)-5-methoxybenzofuran (50 mg, $0.196 \mathrm{mmol})$ and N,Ndimethylaminoethylisothiocyanate $(90 \mathrm{mg}, 0.691 \mathrm{mmol})$ were heated at reflux in ethanol $(4 \mathrm{~mL})$ for $4 \mathrm{~h}$. A colourless precipitate formed that was collected by filtration and washed with diethyl ether (2 x $5 \mathrm{~mL})$ followed by pentane $(2 \times 5 \mathrm{~mL})$. The solid was dried at $50{ }^{\circ} \mathrm{C}$ in vacuo for $4 \mathrm{~h}$ to afford a colourless powder (64 mg, 85\%). ${ }^{1} \mathrm{H}$ NMR [DMSO-d $\left.6,400 \mathrm{MHz}\right]: \delta(\mathrm{ppm}) 9.46(\mathrm{~s}, 1 \mathrm{H}), 8.77$ (s, $1 \mathrm{H}), 8.65(\mathrm{~d}, \mathrm{~J}=1.7 \mathrm{~Hz}, 1 \mathrm{H}), 8.08(\mathrm{dd}, \mathrm{J}=8.7,1.7 \mathrm{~Hz}, 1 \mathrm{H}), 7.97(\mathrm{~s}, 1 \mathrm{H}), 7.49(\mathrm{~d}, \mathrm{~J}=8.9 \mathrm{~Hz}, 1 \mathrm{H})$, $7.21(\mathrm{~s}, 1 \mathrm{H}), 7.12(\mathrm{~d}, \mathrm{~J}=2.5 \mathrm{~Hz}, 1 \mathrm{H}), 6.86(\mathrm{dd}, \mathrm{J}=8.9,2.6 \mathrm{~Hz}, 1 \mathrm{H}), 6.62(\mathrm{~d}, \mathrm{~J}=8.7 \mathrm{~Hz}, 1 \mathrm{H}), 3.79$ $(\mathrm{s}, 3 \mathrm{H}), 3.53(\mathrm{q}, \mathrm{J}=6.1 \mathrm{~Hz}, 2 \mathrm{H}), 2.35(\mathrm{t}, \mathrm{J}=6.7 \mathrm{~Hz}, 2 \mathrm{H}), 2.11(\mathrm{~s}, 6 \mathrm{H}) ;{ }^{13} \mathrm{C}\left\{{ }^{1} \mathrm{H}\right\}$ NMR [DMSO-d $\mathrm{d}_{6}$, $101 \mathrm{MHz}]: \delta(\mathrm{ppm}) 186.1,159.5,155.8,154.4,148.9,144.5,134.2,129.6,118.2,112.5,111.4$, 106.6, 103.3, 100.5, 57.6, 55.6, 45.1, 41.3; ESI-MS (+ve ion): $m / z 386.1650$ (experimental), 386.1651 (calculated for $\left.\left[\mathrm{C}_{19} \mathrm{H}_{24} \mathrm{~N}_{5} \mathrm{O}_{2} \mathrm{~S}\right]^{+}\right) . \lambda_{\max }(\mathrm{DMSO}) \mathrm{nm}\left(\varepsilon / \mathrm{dm}^{3} \mathrm{~mol}^{-1} \mathrm{~cm}^{-1}\right) 325$ (34397), 421 (26264). $\lambda_{\mathrm{ex}}=330 \mathrm{~nm}\left(\lambda_{\mathrm{em}}=398 \mathrm{~nm}\right)$.

$\mathrm{H}_{2} \boldsymbol{L}^{3}$

A mixture of 2-(6-hydrazinyl-3-pyridinyl)-5-benzofuranol (110 $\mathrm{mg}, 0.456 \mathrm{mmol})$ and methyl isothiocyanate $(67 \mathrm{mg}, 0.912 \mathrm{mmol})$ were heated at reflux in ethanol $(4 \mathrm{~mL})$ for $4 \mathrm{~h}$. A brown precipitate formed that was collected by filtration, washed with diethyl ether $(2 \times 5 \mathrm{~mL})$ followed by pentane $(2 \times 5 \mathrm{~mL})$. The solid was dried at $50{ }^{\circ} \mathrm{C}$ in vacuo for $4 \mathrm{~h}$ to afford a brown powder (119 mg, 83\%). ${ }^{1} \mathrm{H}$ NMR [DMSO-d 6 , $400 \mathrm{MHz}$ : $\delta(\mathrm{ppm}) 9.40$ (s, 1H), 9.17 (s, 1H), 8.73 (s, 1H), 8.62 (d, $\mathrm{J}=2.0 \mathrm{~Hz}, 1 \mathrm{H}), 8.16(\mathrm{~d}, \mathrm{~J}=3.4 \mathrm{~Hz}, 1 \mathrm{H}), 8.04(\mathrm{dd}, \mathrm{J}=8.7,2.2 \mathrm{~Hz}, 1 \mathrm{H}), 7.37(\mathrm{~d}, \mathrm{~J}=8.8 \mathrm{~Hz}, 1 \mathrm{H})$, $7.12(\mathrm{~s}, 1 \mathrm{H}), 6.90(\mathrm{~d}, \mathrm{~J}=2.3 \mathrm{~Hz}, 1 \mathrm{H}), 6.70(\mathrm{dd}, \mathrm{J}=8.8,2.4 \mathrm{~Hz}, 1 \mathrm{H}), 6.62(\mathrm{~d}, \mathrm{~J}=8.7 \mathrm{~Hz}, 1 \mathrm{H}), 2.88$ $(\mathrm{d}, \mathrm{J}=4.4 \mathrm{~Hz}, 3 \mathrm{H}) .{ }^{13} \mathrm{C}\left\{{ }^{1} \mathrm{H}\right\}$ NMR [DMSO-d, $\left.126 \mathrm{MHz}\right]: \delta(\mathrm{ppm}) 182.57,159.3,154.1,153.5$, $148.2,144.4,134.1,129.7,118.1,112.7,111.1,106.6,105.1,100.2,39.5,30.8 . \mathrm{m} / \mathrm{z} 315.0913$ (experimental), 315.0916 (calculated for $\left.\left[\mathrm{C}_{15} \mathrm{H}_{15} \mathrm{~N}_{4} \mathrm{O}_{2} \mathrm{~S}\right]^{+}\right) \cdot \lambda_{\max }(\mathrm{DMSO}) \mathrm{nm}\left(\varepsilon / \mathrm{dm}^{3} \mathrm{~mol}^{-1} \mathrm{~cm}^{-1}\right) 332$ (35323). $\lambda_{\mathrm{ex}}=333 \mathrm{~nm}\left(\lambda_{\mathrm{em}}=401 \mathrm{~nm}\right)$. RP-HPLC (Column 2, System A): $\mathrm{R}_{\mathrm{T}}(\mathrm{min}) 8.2$

$\mathrm{H}_{2} \boldsymbol{L}^{4}$

A mixture of 2-(6-hydrazinyl-3-pyridinyl)-5-benzofuranol (110 mg, $0.456 \mathrm{mmol})$ and N,Ndimethylaminoethylisothiocyanate $(119 \mathrm{mg}, 0.912 \mathrm{mmol})$ were heated at reflux in ethanol $(8 \mathrm{~mL})$ for $4 \mathrm{~h}$. The off-white precipitate that formed was collected by filtration and washed with cold ethanol (1-2 mL), diethyl ether $(2 \times 5 \mathrm{~mL})$ followed by pentane $(2 \times 5 \mathrm{~mL})$. The solid was dried at $50{ }^{\circ} \mathrm{C}$ in vacuo for $4 \mathrm{~h}$ to afford a colourless powder $(127 \mathrm{mg}, 75 \%) .{ }^{1} \mathrm{H}$ NMR [DMSO-d ${ }_{6}, 400$ $\mathrm{MHz}$ : $\delta(\mathrm{ppm}) 9.46(\mathrm{~s}, 1 \mathrm{H}), 9.18(\mathrm{~s}, 1 \mathrm{H}), 8.74(\mathrm{~s}, 1 \mathrm{H}), 8.63(\mathrm{~d}, \mathrm{~J}=2.0 \mathrm{~Hz}, 1 \mathrm{H}), 8.05$ (dd, J = 8.7, $2.0 \mathrm{~Hz}, 1 \mathrm{H}), 7.97(\mathrm{~s}, 1 \mathrm{H}), 7.37(\mathrm{~d}, \mathrm{~J}=8.8 \mathrm{~Hz}, 1 \mathrm{H}), 7.13(\mathrm{~s}, 1 \mathrm{H}), 6.90(\mathrm{~d}, \mathrm{~J}=2.4 \mathrm{~Hz}, 1 \mathrm{H}), 6.71(\mathrm{dd}, \mathrm{J}$ $=8.8,2.4 \mathrm{~Hz}, 1 \mathrm{H}), 6.62(\mathrm{~d}, \mathrm{~J}=8.7 \mathrm{~Hz}, 1 \mathrm{H}), 3.53(\mathrm{q}, \mathrm{J}=6.1 \mathrm{~Hz}, 2 \mathrm{H}), 2.36(\mathrm{t}, \mathrm{J}=6.7 \mathrm{~Hz}, 2 \mathrm{H}), 2.11$ $(\mathrm{s}, 6 \mathrm{H}) .{ }^{13} \mathrm{C}\left\{{ }^{1} \mathrm{H}\right\}$ NMR [DMSO-d $\left.{ }_{6}, 126 \mathrm{MHz}\right]: \delta(\mathrm{ppm}) 181.8,159.3,154.0,153.5,148.2,144.4$, $134.1,129.7,118.3,112.7,111.1,106.6,105.1,100.3,57.5,45.1,41.3$. ESI-MS (+ve ion): $m / z$ 
372.1493 (experimental), 372.1494 (calculated for $\left.\left[\mathrm{C}_{18} \mathrm{H}_{22} \mathrm{~N}_{5} \mathrm{O}_{2} \mathrm{~S}\right]^{+}\right) \cdot \lambda_{\max }(\mathrm{DMSO}) \mathrm{nm}\left(\varepsilon / \mathrm{dm}^{3} \mathrm{~mol}^{-1} \mathrm{~cm}^{-}\right.$ 1) 332 (33994). $\lambda_{\mathrm{ex}}=332 \mathrm{~nm}\left(\lambda_{\mathrm{em}}=396 \mathrm{~nm}\right)$. RP-HPLC (Column 2, System A): $\mathrm{R}_{\mathrm{T}}(\mathrm{min}) 8.2$

\section{$H_{2} \boldsymbol{L}^{5}$}

A mixture of (E)-4-(4-hydrazinylstyryl)-N,N-dimethylaniline (60 mg, $0.237 \mathrm{mmol})$ and methyl isothiocyanate $(35 \mathrm{mg}, 0.474 \mathrm{mmol})$ were heated at reflux in ethanol $(4 \mathrm{~mL})$ for $4 \mathrm{~h}$. The light green-brown precipitate that formed was collected by filtration and washed with diethyl ether $(2 \times 5$ $\mathrm{mL})$ followed by pentane $(2 \times 5 \mathrm{~mL})$. The solid was dried at $50^{\circ} \mathrm{C}$ in vacuo for $4 \mathrm{~h}$ to afford a light green-brown powder (66 mg, 85\%). ${ }^{1} \mathrm{H}$ NMR [DMSO-d $\left.{ }_{6}, 400 \mathrm{MHz}\right]: \delta(\mathrm{ppm}) 9.32(\mathrm{~s}, 1 \mathrm{H}), 8.41$ (s, $1 \mathrm{H}), 8.21(\mathrm{~d}, \mathrm{~J}=1.0 \mathrm{~Hz}, 1 \mathrm{H}), 8.11(\mathrm{~s}, 1 \mathrm{H}), 7.85(\mathrm{dd}, \mathrm{J}=8.7,1.5 \mathrm{~Hz}, 1 \mathrm{H}), 7.38(\mathrm{~d}, \mathrm{~J}=8.6 \mathrm{~Hz}, 2 \mathrm{H})$, $6.98(\mathrm{~d}, \mathrm{~J}=16.4 \mathrm{~Hz}, 1 \mathrm{H}), 6.88(\mathrm{~d}, \mathrm{~J}=16.5 \mathrm{~Hz}, 1 \mathrm{H}), 6.71(\mathrm{~d}, \mathrm{~J}=8.7 \mathrm{~Hz}, 2 \mathrm{H}), 6.52$ (d, J = 8.7 Hz, 1H), $2.92(\mathrm{~s}, 6 \mathrm{H}), 2.88(\mathrm{~d}, \mathrm{~J}=4.3 \mathrm{~Hz}, 3 \mathrm{H}) .{ }^{13} \mathrm{C}\left\{{ }^{1} \mathrm{H}\right\}$ NMR [DMSO-d, $126 \mathrm{MHz}$ : $\delta(\mathrm{ppm})$ 182.6, 158.1, 149.7, 146.1, 133.9, 127.1, 126.6, 125.8, 125.2, 120.3, 112.3, 106.8, 40.0, 30.7. ESI-MS (+ve ion): $m / z 328.1594$ (experimental), 328.1596 (calculated for $\left.\left[\mathrm{C}_{17} \mathrm{H}_{22} \mathrm{~N}_{5} \mathrm{~S}\right]^{+}\right) . \lambda_{\max }(\mathrm{DMSO}) \mathrm{nm}\left(\varepsilon / \mathrm{dm}^{3}\right.$ $\left.\mathrm{mol}^{-1} \mathrm{~cm}^{-1}\right) 368$ (36009). $\lambda_{\mathrm{ex}}=370 \mathrm{~nm}\left(\lambda_{\mathrm{em}}=458 \mathrm{~nm}\right)$. RP-HPLC (Column 2, System A): $\mathrm{R}_{\mathrm{T}}(\min )$ 11.0

$H_{2} L^{6}$

A mixture of (E)-4-(4-hydrazinylstyryl)-N,N-dimethylaniline (75 mg, $0.294 \mathrm{mmol}$ ) and N,Ndimethylaminoethylisothiocyanate $(115 \mathrm{mg}, 0.881 \mathrm{mmol})$ were heated at reflux in ethanol $(4 \mathrm{~mL})$ for $4 \mathrm{~h}$. A light green-brown precipitate was observed, collected by filtration and washed with diethyl ether $(2 \times 5 \mathrm{~mL})$ followed by pentane $(2 \times 5 \mathrm{~mL})$. The solid was dried at $50^{\circ} \mathrm{C}$ in vacuo for 4 $\mathrm{h}$ to afford a light green-brown powder $(68.4 \mathrm{mg}, 61 \%) .{ }^{1} \mathrm{H}$ NMR [DMSO-d $\left.\mathrm{d}_{6}, 400 \mathrm{MHz}\right]: \delta(\mathrm{ppm})$ $9.38(\mathrm{~s}, 1 \mathrm{H}), 8.43(\mathrm{~s}, 1 \mathrm{H}), 8.21(\mathrm{~d}, \mathrm{~J}=1.9 \mathrm{~Hz}, 1 \mathrm{H}), 7.91(\mathrm{~s}, 1 \mathrm{H}), 7.86(\mathrm{dd}, \mathrm{J}=8.7,2.0 \mathrm{~Hz}, 1 \mathrm{H}), 7.38$ $(\mathrm{d}, \mathrm{J}=8.8 \mathrm{~Hz}, 2 \mathrm{H}), 6.99(\mathrm{~d}, \mathrm{~J}=16.4 \mathrm{~Hz}, 1 \mathrm{H}), 6.88(\mathrm{~d}, \mathrm{~J}=16.4 \mathrm{~Hz}, 1 \mathrm{H}), 6.71(\mathrm{~d}, \mathrm{~J}=8.8 \mathrm{~Hz}, 2 \mathrm{H})$, $6.52(\mathrm{~d}, \mathrm{~J}=8.7 \mathrm{~Hz}, 1 \mathrm{H}), 3.52(\mathrm{q}, \mathrm{J}=6.1 \mathrm{~Hz}, 2 \mathrm{H}), 2.92(\mathrm{~s}, 6 \mathrm{H}), 2.35(\mathrm{t}, \mathrm{J}=6.7 \mathrm{~Hz}, 2 \mathrm{H}), 2.10(\mathrm{~s}, 6 \mathrm{H})$. ${ }^{13} \mathrm{C}\left\{{ }^{1} \mathrm{H}\right\}$ NMR [DMSO-d $\left.6126 \mathrm{MHz}\right]: \delta(\mathrm{ppm}) 181.8,158.1,149.8,146.2,134.0,127.1,126.8$, $126.0,125.2,120.3,112.3,106.8,57.6,45.1,41.2$, 40.0. ESI-MS (+ve ion): $\mathrm{m} / \mathrm{z} 385.2155$ (experimental), 385.2174 (calculated for $\left.\left[\mathrm{C}_{20} \mathrm{H}_{29} \mathrm{~N}_{6} \mathrm{~S}\right]^{+}\right) \cdot \lambda_{\max }(\mathrm{DMSO}) \mathrm{nm}\left(\varepsilon / \mathrm{dm}^{3} \mathrm{~mol}^{-1} \mathrm{~cm}^{-1}\right) 369$ (35496). $\lambda_{\mathrm{ex}}=370 \mathrm{~nm}\left(\lambda_{\mathrm{em}}=461 \mathrm{~nm}\right)$. RP-HPLC (Column 2, System A): $\mathrm{R}_{\mathrm{T}}(\mathrm{min}) 10.3$. 


\section{General procedure for the syntheses of $\operatorname{Re}(\mathrm{V})$ complexes}

A mixture of ligands, $\mathrm{H}_{2} \mathbf{L}^{1-6}(2.1$ eq) and oxotrichlorobis(triphenylphosphine)rhenium(V), $\left[\mathrm{ReOCl}_{3}\left(\mathrm{PPh}_{3}\right)_{2}\right],[47]$ (1 eq) were heated at reflux in methanol $(20 \mathrm{~mL})$ for $4 \mathrm{~h}$. A dark red-brown precipitate was collected by filtration and washed with cold methanol $(2-5 \mathrm{~mL})$, diethyl ether $(2 \mathrm{x}$ $5-20 \mathrm{~mL})$ followed by pentane $(2 \times 5-20 \mathrm{~mL})$. The solid was dried at $50^{\circ} \mathrm{C}$ in vacuo for $4 \mathrm{~h}$ to afford a red-brown powder.

$\left[\mathrm{ReO}\left(\mathrm{HL}^{\mathrm{I}}\right)_{2}\right] \mathrm{Cl}$

Synthesised by general procedure with $\mathrm{H}_{2} \mathbf{L}^{1} \quad\left(\begin{array}{lllll}150 & \mathrm{mg}, & 0.457 & \mathrm{mmol}\end{array}\right)$, oxotrichlorobis(triphenylphosphine)rhenium(V) (181 mg, $0.218 \mathrm{mmol})$ and methanol (15 $\mathrm{mL})$, a red-brown powder (130 mg, 67\%). ${ }^{1} \mathrm{H}$ NMR [DMSO-d $\left.6,400 \mathrm{MHz}\right]$ : $\delta(\mathrm{ppm}) 8.56(\mathrm{~s}, 4 \mathrm{H}), 7.94$ (d, J $=9.7 \mathrm{~Hz}, 2 \mathrm{H}), 7.59(\mathrm{~d}, \mathrm{~J}=9.0 \mathrm{~Hz}, 2 \mathrm{H}), 7.51(\mathrm{~s}, 2 \mathrm{H}), 7.22(\mathrm{~d}, \mathrm{~J}=2.5 \mathrm{~Hz}, 2 \mathrm{H}), 6.97$ (dd, J = 8.9, 2.5 $\mathrm{Hz}, 2 \mathrm{H}), 3.82$ (s, 6H), 3.08 (s, 6H). ESI-MS (+ve ion): $\mathrm{m} / z$ 857.1252 (experimental), 857.1333 (calculated for $\left.\left[\mathrm{C}_{32} \mathrm{H}_{30} \mathrm{~N}_{8} \mathrm{O}_{5} \mathrm{ReS}_{2}\right]^{+}\right) . \lambda_{\max }(\mathrm{DMSO}) \mathrm{nm}\left(\varepsilon / \mathrm{dm}^{3} \mathrm{~mol}^{-1} \mathrm{~cm}^{-1}\right) 329$ (42268), 429 (30317). $\lambda_{\mathrm{ex}}$ $=332 \mathrm{~nm}\left(\lambda_{\mathrm{em}}=391 \mathrm{~nm}\right)$. RP-HPLC (Column 2, System A): $\mathrm{R}_{\mathrm{T}}(\mathrm{min})$ 18.3. IR: $\overline{\mathrm{u}}_{\max }\left(\mathrm{cm}^{-1}\right) 961\left(\mathrm{v}_{\mathrm{Re}=\mathrm{O}}\right)$, $3102\left(\mathrm{v}_{\mathrm{N}-\mathrm{H}}\right)$.

$\left[\mathrm{ReO}\left(\mathrm{HL}^{2}\right)_{2}\right] \mathrm{Cl}$

Synthesised by general procedure with $\mathrm{H}_{2} \mathbf{L}^{2}(50 \mathrm{mg}, \quad 0.129 \mathrm{mmol})$, oxotrichlorobis(triphenylphosphine)rhenium(V) $(50 \mathrm{mg}, 0.060 \mathrm{mmol})$ and methanol $(4 \mathrm{~mL})$, a redbrown powder (41 mg, 70\%). ${ }^{1} \mathrm{H}$ NMR (DMSO-d, $\left.400 \mathrm{MHz}\right]: \delta(\mathrm{ppm}) 10.65$ (s, 2H), 8.77 (s, 2H), 8.55 (s, 2H), 7.92 (s, 2H), 7.76 (s, 2H), 7.60 (d, J = $8.9 \mathrm{~Hz}, 2 \mathrm{H}), 7.48$ (s, 2H), 7.22 (d, J = 2.2 Hz, 2H), $6.96(\mathrm{dd}, \mathrm{J}=8.9,2.2 \mathrm{~Hz}, 2 \mathrm{H}), 3.92(\mathrm{~d}, \mathrm{~J}=52.1 \mathrm{~Hz}, 4 \mathrm{H}), 3.82$ (s, 6H), 2.84 (s, 12H). ESI-MS (+ve ion): $m / z 971.2484$ (experimental), 971.2490 (calculated for $\left[\mathrm{C}_{38} \mathrm{H}_{44} \mathrm{~N}_{10} \mathrm{O}_{5} \mathrm{ReS}_{2}\right]^{+}$). $\lambda_{\max }(\mathrm{DMSO})$ $\mathrm{nm}\left(\varepsilon / \mathrm{dm}^{3} \mathrm{~mol}^{-1} \mathrm{~cm}^{-1}\right) 323$ (34397), 424 (26264). $\lambda_{\mathrm{ex}}=320 \mathrm{~nm}\left(\lambda_{\mathrm{em}}=385 \mathrm{~nm}\right) . \mathrm{IR}: \overline{\mathrm{u}}_{\max }\left(\mathrm{cm}^{-1}\right) 966$ $\left(v_{\mathrm{Re}=\mathrm{O}}\right), 2620\left(\mathrm{v}_{\mathrm{N}-\mathrm{H}}\right)$.

$\left[\mathrm{ReO}\left(\mathrm{HL}^{3}\right)_{2}\right] \mathrm{Cl}$

Synthesised by general procedure with $\mathrm{H}_{2} \mathbf{L}^{3}(100 \mathrm{mg}, \quad 0.318 \mathrm{mmol})$, oxotrichlorobis(triphenylphosphine)rhenium(V) (126 mg, $0.151 \mathrm{mmol})$ and methanol (10 $\mathrm{mL})$, a red-brown powder (110 mg, 84\%). ${ }^{1} \mathrm{H}$ NMR (DMSO-d $6,400 \mathrm{MHz}$ : $\delta(\mathrm{ppm}) 8.53$ (s, 4H), 7.94 (d, J $=9.6 \mathrm{~Hz}, 2 \mathrm{H}), 7.47(\mathrm{~d}, \mathrm{~J}=8.9 \mathrm{~Hz}, 2 \mathrm{H}), 7.43(\mathrm{~s}, 2 \mathrm{H}), 7.00(\mathrm{~d}, \mathrm{~J}=2.4 \mathrm{~Hz}, 2 \mathrm{H}), 6.81$ (dd, J = 8.8, 2.4 $\mathrm{Hz}, 2 \mathrm{H}), 3.07$ (s, 6H). ${ }^{13} \mathrm{C}\left\{{ }^{1} \mathrm{H}\right\}$ NMR [DMSO-d $\left.{ }_{6}, 126 \mathrm{MHz}\right]: \delta(\mathrm{ppm})$ 167.4, 153.9, 150.8, 148.6, 138.0, 133.1, 129.2, 128.7, 123.4, 118.4, 114.1, 111.5, 105.6, 103.7, 33.3. ESI-MS (+ve ion): [M] ${ }^{+}$ $m / z 829.1015$ (experimental), 829.1020 (calculated for $\left.\left[\mathrm{C}_{30} \mathrm{H}_{26} \mathrm{~N}_{8} \mathrm{O}_{5} \mathrm{ReS}_{2}\right]^{+}\right) . \lambda_{\max }(\mathrm{DMSO}) \mathrm{nm}\left(\varepsilon / \mathrm{dm}^{3}\right.$ $\left.\mathrm{mol}^{-1} \mathrm{~cm}^{-1}\right) 329$ (41299), 429 (29950). $\lambda_{\mathrm{ex}}=330 \mathrm{~nm}\left(\lambda_{\mathrm{em}}=390 \mathrm{~nm}\right)$. RP-HPLC (Column 2, System A): $\mathrm{R}_{\mathrm{T}}(\min )$ 14.1. IR: $\overline{\mathrm{U}}_{\max }\left(\mathrm{cm}^{-1}\right) 954\left(\mathrm{v}_{\mathrm{Re}=\mathrm{O}}\right), 3356\left(\mathrm{v}_{\mathrm{N}-\mathrm{H}}\right), 3148\left(\mathrm{v}_{\mathrm{O}-\mathrm{H}}\right)$.

$\left[\mathrm{ReO}\left(\mathrm{HL}^{4}\right)_{2}\right] \mathrm{Cl}$ 
Synthesised by general procedure with $\mathrm{H}_{2} \mathbf{L}^{4} \quad\left(\begin{array}{lllll}100 & \mathrm{mg}, & 0.269 & \mathrm{mmol}\end{array}\right)$, oxotrichlorobis(triphenylphosphine)rhenium(V) (107 mg, $0.128 \mathrm{mmol})$ and methanol (10 $\mathrm{mL})$, a red-brown powder $(97 \mathrm{mg}, 80 \%) .{ }^{1} \mathrm{H}$ NMR $\left[\mathrm{DMSO}_{6}, 400 \mathrm{MHz}\right]: \delta(\mathrm{ppm}) 10.69(\mathrm{~s}, 2 \mathrm{H}), 9.36(\mathrm{~s}$, 2H), 8.74 (s, 2H), 8.53 (s, 2H), $7.92(\mathrm{~s}, 2 \mathrm{H}), 7.81(\mathrm{~s}, 2 \mathrm{H}), 7.48$ (d, J = 8.7 Hz, 2H), 7.42 (s, 2H), $7.00(\mathrm{~d}, \mathrm{~J}=1.9 \mathrm{~Hz}, 2 \mathrm{H}), 6.81(\mathrm{dd}, \mathrm{J}=8.8,1.8 \mathrm{~Hz}, 2 \mathrm{H}), 3.95(\mathrm{~d}, \mathrm{~J}=53.4 \mathrm{~Hz}, 4 \mathrm{H}), 3.23-3.19(\mathrm{~m}, 4 \mathrm{H})$, $2.84(\mathrm{~s}, 12 \mathrm{H}) .{ }^{13} \mathrm{C}\left\{{ }^{1} \mathrm{H}\right\}$ NMR [DMSO-d, $126 \mathrm{MHz}$ ]: $\delta(\mathrm{ppm})$ 166.7, 153.9, 151.0, 148.6, 133.4, 132.2, 129.3, 123.3, 118.5, 114.1, 111.5, 105.6, 103.7, 54.7, 42.3, 41.0. ESI-MS (+ve ion): $[\mathrm{M}]^{+} \mathrm{m} / \mathrm{z}$ 943.2225 (experimental), 943.2177 (calculated for $\left.\left[\mathrm{C}_{36} \mathrm{H}_{40} \mathrm{~N}_{10} \mathrm{O}_{5} \mathrm{ReS}_{2}\right]^{\dagger}\right) \cdot \lambda_{\max }(\mathrm{DMSO}) \mathrm{nm}\left(\varepsilon / \mathrm{dm}^{3} \mathrm{~mol}^{-1}\right.$ $\left.\mathrm{cm}^{-1}\right) 323$ (38583), 423 (29700). $\lambda_{\mathrm{ex}}=324 \mathrm{~nm}\left(\lambda_{\mathrm{em}}=390 \mathrm{~nm}\right)$. RP-HPLC (Column 2, System A) $\mathrm{R}_{\mathrm{T}}$ (min) 9.9. IR: $\overline{\mathrm{U}}_{\max }\left(\mathrm{cm}^{-1}\right) 969\left(\mathrm{v}_{\mathrm{Re}=\mathrm{O}}\right), 2560\left(\mathrm{v}_{\mathrm{N}-\mathrm{H}}\right), 3176\left(\mathrm{v}_{\mathrm{O}-\mathrm{H}}\right)$.

$\left[\mathrm{ReO}\left(\mathrm{HL}^{5}\right)_{2}\right] \mathrm{Cl}$

Synthesised by general procedure with $\mathrm{H}_{2} \mathbf{L}^{5}(150 \mathrm{mg}, \quad 0.458 \mathrm{mmol})$, oxotrichlorobis(triphenylphosphine)rhenium(V) (182 mg, $0.218 \mathrm{mmol})$ and methanol (15 $\mathrm{mL})$, a red-brown powder (97 mg, 50\%). ${ }^{1} \mathrm{H}$ NMR [DMSO-d $\mathrm{D}_{6}, 400 \mathrm{MHz}$ : $\delta(\mathrm{ppm}) 8.55$ (dd, J = 9.6, $1.9 \mathrm{~Hz}$, 2H), $8.21(\mathrm{~s}, 2 \mathrm{H}), 7.84(\mathrm{~d}, \mathrm{~J}=9.4 \mathrm{~Hz}, 2 \mathrm{H}), 7.54(\mathrm{~d}, \mathrm{~J}=8.2 \mathrm{~Hz}, 6 \mathrm{H}), 7.28(\mathrm{~d}, \mathrm{~J}=16.4 \mathrm{~Hz}, 2 \mathrm{H}), 7.20$ $(\mathrm{d}, \mathrm{J}=16.5 \mathrm{~Hz}, 2 \mathrm{H}), 6.94(\mathrm{~s}, 4 \mathrm{H}), 3.07$ (s, 6H), 3.00 (s, 12H). ESI-MS (+ve ion): $\mathrm{m} / z$ 855.2306 (experimental), 855.2380 (calculated for $\left.\left[\mathrm{C}_{34} \mathrm{H}_{40} \mathrm{~N}_{10} \mathrm{OReS}_{2}\right]^{+}\right) . \lambda_{\max }(\mathrm{DMSO}) \mathrm{nm}\left(\varepsilon / \mathrm{dm}^{3} \mathrm{~mol}^{-1} \mathrm{~cm}^{-1}\right) 353$ (41915), 467 (33322). $\lambda_{\mathrm{ex}}=370 \mathrm{~nm}\left(\lambda_{\mathrm{em}}=453 \mathrm{~nm}\right)$. RP-HPLC (Column 2, System A): $\mathrm{R}_{\mathrm{T}}(\mathrm{min})$ 13.6. IR: $\overline{\mathrm{u}}_{\max }\left(\mathrm{cm}^{-1}\right) 955\left(\mathrm{v}_{\mathrm{Re}=\mathrm{O}}\right), 3017\left(\mathrm{v}_{\mathrm{N}-\mathrm{H}}\right)$.

$\left[\mathrm{ReO}\left(\mathrm{HL}^{6}\right)_{2}\right] \mathrm{Cl}$

Synthesised by modified general procedure with $\mathrm{H}_{2} \mathbf{L}^{6}(90 \mathrm{mg}, 0.234 \mathrm{mmol})$, oxotrichlorobis(triphenylphosphine)rhenium(V) $(93 \mathrm{mg}, 0.111 \mathrm{mmol})$ and methanol $(9 \mathrm{~mL})$. The solvent was removed under reduced pressure and the remaining solid was heated in methanol:acetone $(10: 9040 \mathrm{~mL})$. A dark brown solid was collect by hot filtration $(30 \mathrm{mg}, 27 \%)$. ${ }^{1} \mathrm{H}$ NMR [DMSO-d, 400 MHz]: $\delta(\mathrm{ppm}) 10.57$ (s, 1H), 8.45 (d, J = $75.3 \mathrm{~Hz}, 4 \mathrm{H}), 7.85$ (s, 2H), 7.48 (d, $\mathrm{J}=7.9 \mathrm{~Hz}, 4 \mathrm{H}), 7.20(\mathrm{t}, \mathrm{J}=17.6 \mathrm{~Hz}, 4 \mathrm{H}), 6.76(\mathrm{~d}, \mathrm{~J}=8.3 \mathrm{~Hz}, 4 \mathrm{H}), 3.94(\mathrm{~d}, \mathrm{~J}=85.8 \mathrm{~Hz}, 4 \mathrm{H}), 2.96$ (s, 12H), 2.82 (s, 12H). ESI-MS (+ve ion): $m / z 485.1782$ (experimental), 485.1805 (calculated for $\left.\left[\mathrm{C}_{40} \mathrm{H}_{55} \mathrm{~N}_{12} \mathrm{OReS}_{2}\right]^{2+}\right) \cdot \lambda_{\max }(\mathrm{DMSO}) \mathrm{nm}\left(\varepsilon / \mathrm{dm}^{3} \mathrm{~mol}^{-1} \mathrm{~cm}^{-1}\right) 355$ (36231), 425 (32650). $\lambda_{\mathrm{ex}}=370 \mathrm{~nm}\left(\lambda_{\mathrm{em}}=\right.$ $462 \mathrm{~nm}$ ). RP-HPLC (Column 2, System A): $\mathrm{R}_{\mathrm{T}}(\mathrm{min}) 11.7$.

\section{A $\beta$ fibril binding assays}

$\mathrm{AB}_{1-42}$ was synthesized using solid phase peptide synthesizer (Liberty Blue peptide synthesizer, Biostage) using F-moc chemistry on a $0.1 \mathrm{mM}$ scale using reported procedure.[48] Synthetic peptide was dissolved in HFIP ( $1 \mathrm{mg}$ per $221.7 \mu \mathrm{L}$ HFIP) incubated for 1 hour on ice then allowed to evaporate overnight in fume hood. The residue was further dried under high vacuum to remove any residual HFIP and moisture and then stored at $-80^{\circ} \mathrm{C}$. For a $1 \mathrm{mg} / \mathrm{mL}$ stock solution in PBS, the 
HFIP treated peptide was dissolved in 2 parts of $60 \mathrm{mM} \mathrm{NaOH}$ and incubated for 3 min at room temperature. To this solution 7 parts of de-ionized water was added and vortex briefly followed by ultrasonication for 5 minutes on ice. Added 1 part of 10x PBS, vortex briefly and centrifuged for 5 min. Supernatant was transferred to a fresh tube and kept on ice. The concentration of the stock solution was determined by measuring the absorbance at $214 \mathrm{~nm}\left(\varepsilon=75887 \mathrm{M}^{-1} \mathrm{~cm}^{-1}\right)$.

Stock solutions of ThT (1 mM in PBS), and Re(V) complexes (1 mM in DMSO) were freshly prepared. Final sample were composed $A \beta_{-42}(1$ eq., $10 \mu \mathrm{M})$, ThT (4 eq., $\left.40 \mu \mathrm{M}\right)$ and the Re complexes (2 eq. $20 \mu \mathrm{M}$ ) to make a final volume of $500 \mu \mathrm{L}$ in PBS with $2.5 \%$ DMSO. Samples were transferred on a 96 well plates kept over ice having $150 \mu \mathrm{L}$ in each well to analyze in triplicates. The ThT fluorescence intensity of each sample was recorded every $12.5 \mathrm{~min}$ at $37{ }^{\circ} \mathrm{C}$ using an OPTIMA fluorescent plate reader with 440/480 $\pm 10 \mathrm{~nm}$ excitation/emission filters over a period of $52 \mathrm{~h}$.

\section{Human brain tissue staining}

Paraffin preserved brain tissue blocks were provided by the Victorian Brain Bank Network. Brain tissue was collected at autopsy. The National Neural Tissue Resource Centre performed sourcing and preparation of human brain tissue. AD pathologic diagnosis was made according to standard National Institute on Ageing-Reagan Institute criteria. Determination of age matched human control (HC) cases was subject to the above criteria. The AD and HC brain tissues sections $(7 \mu \mathrm{m})$ were first deparaffined (xylene, $3 \times 2 \mathrm{~min}$ ) followed by rehydration (soaking in a series of 100\%, 90\%, $70 \%$, and $0 \% \mathrm{v} / \mathrm{v}$ ethanol/water baths). The hydrated tissue sections were washed in phosphate buffer saline (PBS, 5min). Autofluorescence of tissues was quenched using potassium permanganate $(0.25 \%$ in PBS, $20 \mathrm{~min})$ and washing with PBS $(2 \times 2 \mathrm{~min})$ to remove the excess. The now brown coloured sections were washed with potassium metabisulfite and oxalic acid (1\% in PBS) until brown colour was removed followed by washing with PBS ( $3 \times 2 \mathrm{~min}$ ). The sections were blocked with bovine serum albumin (2\% BSA in PBS, pH 7.0, $10 \mathrm{~min})$ and covered with $\left[\mathrm{ReO}\left(\mathrm{HL}^{6}\right)_{2}\right] \mathrm{Cl}(10 \mu \mathrm{m}$ in $15 \% \mathrm{v} / \mathrm{v}$ DMSO/PBS, $10 \mathrm{~min})$. The sections were treated with BSA again to remove any unbound compound. Finally, the sections were washed with PBS ( $3 \times 2 \mathrm{~min})$, deionised water, and mounted with non-fluorescent mounting media (Dako). Florescence images were visualised using a Leica DM IL LED Fluoresence microscope fitted with a Leica DFC310FX color camera.

\section{Radiolabelling with ${ }^{99 \mathrm{~m}} \mathrm{Tc}$}

Radiolabelling with Techentium-99m was carried out with the addition of ligands, $\mathbf{H}_{2} \mathbf{L} \mathbf{2}^{-10}$ in EtOH $\left(1 \mathrm{mg} \mathrm{mL}^{-1}\right)$ to a solution of tin chloride in $\mathrm{EtOH}\left(1 \mathrm{mg} \mathrm{mL}{ }^{-1}\right)$. A $100 \mu \mathrm{L}$ aliquot of eluted sodium 
pertechnetate $\left(\left[{ }^{99 \mathrm{~m}} \mathrm{TcO}_{4}\right], 1 \mathrm{ml}\right.$ in $0.9 \%$ saline, $\left.\sim 1000 \mathrm{MBq}\right)$ was added and the mixture was left for 30 min. A $20 \mu \mathrm{L}$ aliquot was used to assess the purity of the radiochemical product using RP-HPLC.

\section{Crystallography}

Intensity data were collected with an Oxford Diffraction SuperNova CCD diffractometer using $\mathrm{Cu}$ $\mathrm{K}$ radiation, the temperature during data collection was maintained at 130.0(1) K using an Oxford Cryosystems cooling device. The structures were solved by direct methods and difference Fourier synthesis.[49] Thermal ellipsoid plots were generated using the program ORTEP-3 integrated within the WINGX suite of programs.[50]

Crystal data for $\left[\mathrm{ReO}\left(\mathrm{H}_{2} \mathrm{~L}^{4}\right)_{2}\right]\left(\mathrm{BF}_{4}\right)_{3} .2 \mathrm{DMF}: \mathrm{C}_{42} \mathrm{H}_{55} \mathrm{~B}_{2} \mathrm{~F}_{8} \mathrm{~N}_{12} \mathrm{O}_{7} \mathrm{ReS}_{2} M=1263.92 T=130.0 \mathrm{~K}$, = $1.54184 \AA$ A, space group C $2 / \mathrm{c}, a=16.937(3) b=24.270(3), c=16.9438(19) \AA$, $=111.774(17)^{\circ}$ $V=6467.9(17) \AA^{3}, \mathrm{Z}=4, \mathrm{D}_{\mathrm{c}}=1.298 \mathrm{Mg} \mathrm{M}^{-3}(\mathrm{Cu}-\mathrm{K}) 4.899 \mathrm{~mm}^{-1}, \mathrm{~F}(000)=2544$, crystal size 0.41 x $0.03 \times 0.02 \mathrm{~mm}^{3}, 18209$ reflections measured ${ }_{\max }=67.5^{\circ}, 5829$ independent reflections $[\mathrm{R}(\mathrm{int})=$ 0.0865], the final $\mathrm{R}$ was $0.0706\left[\mathrm{I}>2\right.$ (I) 4123 data] and $w \mathrm{R}\left(\mathrm{F}^{2}\right)$ was 0.2144 (all data), GOOF $=$ 0.957 .

Crystal data for $\left[\mathrm{ReO}\left(\mathrm{HL}^{6}\right)\left(\mathbf{L}^{6}\right)\right]: \mathrm{C}_{40} \mathrm{H}_{53} \mathrm{~N}_{12} \mathrm{ORe} \mathrm{S}_{2} .0 .5\left(\mathrm{H}_{2} \mathrm{O}\right) M=976.26, T=130.0 \mathrm{~K}, \quad=1.54184$ $\AA$, space group P-1, $a=10.2115(12) b=13.740(2)), c=18.614\left(3 \AA,=103.960(13)^{\circ}=\right.$ $94.436(10)^{\circ}=94.116(11)^{\circ} \mathrm{V}=2515.9(6) A^{3}, \mathrm{Z}=2, \mathrm{D}_{\mathrm{c}}=1.289 \mathrm{Mg} \mathrm{M}^{-3}(\mathrm{Cu}-\mathrm{K}) 5.287 \mathrm{~mm}^{-1}$, $\mathrm{F}(000)=992$, crystal size $0.15 \times 0.07 \times 0.02 \mathrm{~mm}^{3}, 16704$ reflections measured ${ }_{\max }=67.5^{\circ}, 9062$ independent reflections $[\mathrm{R}(\mathrm{int})=0.1240]$, the final $\mathrm{R}$ was $0.0846\left[\mathrm{I}>2\right.$ (I) 4316 data] and $w \mathrm{R}\left(\mathrm{F}^{2}\right)$ was 0.2071 (all data), GOOF $=0.899$.

CCDC deposition numbers: CCDC1840665 and CCDC 1841151

\section{Acknowledgements}

The Australian Research Council for funding this research. The Victorian Brain Bank for provision of human brain tissue. We acknowledge the generous support of Prof. Andrew M. Scott, A/Prof. Henri Tochon-Danguy, A/Prof. Uwe Ackermann, Dr. FT Lee, Nick Alexopoulos, and David Thomas of the Austin Hospital, Heidelberg, Victoria, Australia, for providing access to ${ }^{99 \mathrm{~m}} \mathrm{Tc}$ and radiochemistry facilities. Associate Professors Kevin Barnham and Victor Villemagne are acknowledged for their ongoing advice and guidance in this area of research.

\section{References}

1 M. Schrag and H. Kirshner (2016) Curr Neurol Neurosci Rep 16:76 
3 M. Hecht, L. M. Krämer, C. A. F. von Arnim, M. Otto and D. R. Thal (2018) Acta Neuropathol 135:681-694

4 K. A. Johnson, M. Gregas, J. A. Becker, C. Kinnecom, D. H. Salat, E. K. Moran, E. E. Smith, J. Rosand, D. M. Rentz, W. E. Klunk, C. A. Mathis, J. C. Price, S. T. DeKosky, A. J. Fischman and S. M. Greenberg (2007) Annals of Neurology 62:229-234 C. Cordonnier (2011) Curr Opin Neurol 24:69 - 74

6 Z. Zha, S. R. Choi, K. Ploessl, B. P. Lieberman, W. Qu, F. Hefti, M. Mintun, D. Skovronsky and H. F. Kung (2011) J Med Chem 54:8085-8098

7 W. E. Klunk, Y. Wang, G.-F. Huang, M. L. Debnath, D. P. Holt and C. A. Mathis (2001) Life Sci 69:1471-1484

C. A. Mathis, B. J. Bacskai, S. T. Kajdasz, M. E. McLellan, M. P. Frosch, B. T. Hyman, D. P. Holt, Y. Wang, G.-F. Huang, M. L. Debnath and W. E. Klunk (2002) Bioorg Med Chem Lett 12:295-298

C. C. Rowe, S. Ng, U. Ackermann, S. J. Gong, K. L. Pike, G. Savage, T. F. Cowie, K. L. Dickinson, P. Maruff, D. Darby, C. Smith, M. Woodward, J. Merory, H. Tochon-Danguy, G. O'Keefe, W. E. Klunk, C. A. Mathis, J. C. Price, C. L. Masters and V. L. Villemagne (2007) Neurology 68:1718-1725

10 S. M. Greenberg, T. Grabowski, M. E. Gurol, M. E. Skehan, R. N. K. Nandigam, J. A. Becker, M. Garcia-Alloza, C. Prada, M. P. Frosch, J. Rosand, A. Viswanathan, E. E. Smith and K. A. Johnson (2008) Annals of Neurology 64:587-591

11 H. F. Kung, C.-W. Lee, Z.-P. Zhuang, M.-P. Kung, C. Hou and K. Ploessl (2001) J Am Chem Soc 123:12740-12741

12 N. P. L. G. Verhoeff, A. Wilson, A., S. Takeshita, L. Trop, D. Hussey, K. Singh, H. Kung, F., M.-P. Kung and S. Houle (2004) Am J Geriatr Psychiatry 12:584-595

13 M. Ono, A. Wilson, J. Nobrega, D. Westaway, P. Verhoeff, Z.-P. Zhuang, M.-P. Kung and H. F. Kung (2003) Nucl Med Biol 30:565-571

14 H. F. Kung, S. R. Choi, W. Qu, W. Zhang and D. Skovronsky (2010) J Med Chem 53:933941

15 L. Zhu, K. Ploessl and H. F. Kung (2014) Chem Soc Rev 43:6683-6691

16 B.-M. Swahn, D. Wensbo, J. Sandell, D. Sohn, C. Slivo, D. Pyring, J. Malmstroem, E. Arzel, M. Vallin, M. Bergh, F. Jeppsson, A. E. Johnson, A. Jureus, J. Neelissen and S. Svensson (2010) Bioorg Med Chem Lett 20:1976-1980

17 B.-M. Swahn, J. Sandell, D. Pyring, M. Bergh, F. Jeppsson, A. Jureus, J. Neelissen, P. Johnstroem, M. Schou and S. Svensson (2012) Bioorg Med Chem Lett 22:4332-4337

18 J. L. Hickey and P. S. Donnelly (2012) Coord Chem Rev 256:2367-2380

19 D. J. Hayne, S. C. Lim and P. S. Donnelly (2014) Chem Soc Rev 43:6701-6715

20 K. Chen and M. Cui (2017) MedChemComm 8:1393-1407

21 D. J. Hayne, J. M. White, C. A. McLean, V. L. Villemagne, K. J. Barnham and P. S. Donnelly (2016) Inorg Chem 55:7944-7953

22 D. J. Hayne, A. J. North, M. Fodero-Tavoletti, J. M. White, L. W. Hung, A. Rigopoulos, C. A. McLean, P. A. Adlard, U. Ackermann, H. Tochon-Danguy, V. L. Villemagne, K. J. Barnham and P. S. Donnelly (2015) Dalton Trans 44:4933-4944

23 C. Y. Chan, A. Noor, C. A. McLean, P. S. Donnelly and P. J. Barnard (2017) Chem Commun 53:2311-2314

24 X. Zhang, Y. Hou, C. Peng, C. Wang, X. Wang, Z. Liang, J. Lu, B. Chen, J. Dai, B. Liu and M. Cui (2018) J Med Chem 61:1330-1339

25 Z. Li, M. Cui, J. Dai, X. Wang, P. Yu, Y. Yang, J. Jia, H. Fu, M. Ono, H. Jia, H. Saji and B. Liu (2013) J Med Chem 56:471-482

26 M. Ono, Y. Fuchi, T. Fuchigami, N. Kobashi, H. Kimura, M. Haratake, H. Saji and M. Nakayama (2010) ACS Med Chem Lett 1:443-447

27 M. Ono, R. Ikeoka, H. Watanabe, H. Kimura, T. Fuchigami, M. Haratake, H. Saji and M. Nakayama (2010) Bioorg Med Chem Lett 20:5743-5748 
J. Jia, M. Cui, J. Dai, X. Wang, Y.-S. Ding, H. Jia and B. Liu (2014) MedChemComm 5:153-158

29 X. Wang, M. Cui, J. Jia and B. Liu (2015) Eur J Med Chem 89:331-339

30 X. Zhang, P. Yu, Y. Yang, Y. Hou, C. Peng, Z. Liang, J. Lu, B. Chen, J. Dai, B. Liu and M. Cui (2016) Bioconjugate Chem 27:2493-2504

31 S. Iikuni, M. Ono, K. Tanimura, H. Watanabe, M. Yoshimura and H. Saji (2017) RSC Advances 7:20582-20590

32 J. Jia, M. Cui, J. Dai and B. Liu (2015) Mol Pharmaceutics 12:2937-2946

33 S. Iikuni, M. Ono, H. Watanabe, K. Matsumura, M. Yoshimura, H. Kimura, H. IshibashiUeda, Y. Okamoto, M. Ihara and H. Saji (2016) Sci Rep 6:25990

34 S. Iikuni, M. Ono, H. Watanabe, M. Yoshimura, H. Ishibashi-Ueda, M. Ihara and H. Saji (2016) PLoS One 11:e0163969/0163961-e0163969/0163912

35 C. Clarke, A. R. Cowley, J. R. Dilworth and P. S. Donnelly (2004) Dalton Trans, doi 10.1039/b406439a:2402-2403

36 A. J. North, J. A. Karas, M. T. Ma, P. J. Blower, U. Ackermann, J. M. White and P. S. Donnelly (2017) Inorg Chem 56:9725-9741

37 A. L. Spek (2015) Acta Crystallographica, Section C: Structural Chemistry 71:9-18

38 G. Bandoli and T. I. A. Gerber (1987) Inorg Chim Acta 126:205-208

39 D. Y. Chi and J. A. Katzenellenbogen (1993) J Am Chem Soc 115:7045-7046

40 T. Konno, Y. Shimazaki, M. Kawai and M. Hirotsu (2001) Inorg Chem 40:4250-4256

41 J. M. Mayer (1988) Inorg Chem 27:3899-3903

42 Y. P. Wang, C. M. Che, K. Y. Wong and S. M. Peng (1993) Inorg Chem 32:5827-5832

43 S. Alvarez Luna, C. Bolzati, A. Duatti, G. L. Zucchini, G. Bandoli and F. Refosco (1992) Inorg Chem 31:2595-2598

44 A. R. Cowley, J. R. Dilworth, P. S. Donnelly and J. Woollard-Shore (2003) Dalton Trans, doi 10.1039/b210540n:748-754

45 B. M. Paterson, J. M. White and P. S. Donnelly (2010) Dalton Trans 39:2831-2837

46 J. L. Hickey, S. C. Lim, D. J. Hayne, B. M. Paterson, J. M. White, V. L. Villemagne, P. Roselt, D. Binns, C. Cullinane, C. M. Jeffery, R. I. Price, K. J. Barnham and P. S. Donnelly (2013) J Am Chem Soc 135:16120-16132

47 N. P. Johnson, C. J. L. Lock and G. Wilkinson (1967) Inorg Synth 9:145-148

48 J. A. Karas, A. Noor, C. Schieber, T. U. Connell, F. Separovic and P. S. Donnelly (2017) Chem Commun 53:6903-6905

49 G. M. Sheldrick (2015) Acta Crystallographica, Section C: Structural Chemistry 71:3-8

50 L. J. Farrugia (2012) J Appl Crystallogr 45:849-854

\section{Rhenium and Technetium Complexes of Thioamide Derivatives of Pyridylhydrazine that} Bind to Amyloid- Plaques

Scott E. Fletcher, ${ }^{a}$ Asif Noor, ${ }^{a}$ James L. Hickey, ${ }^{a}$ Catriona A. McLean, ${ }^{b}$ Jonathan M. White ${ }^{a}$ and Paul S. Donnelly ${ }^{a} *$

Table of Contents Graphical Entry 


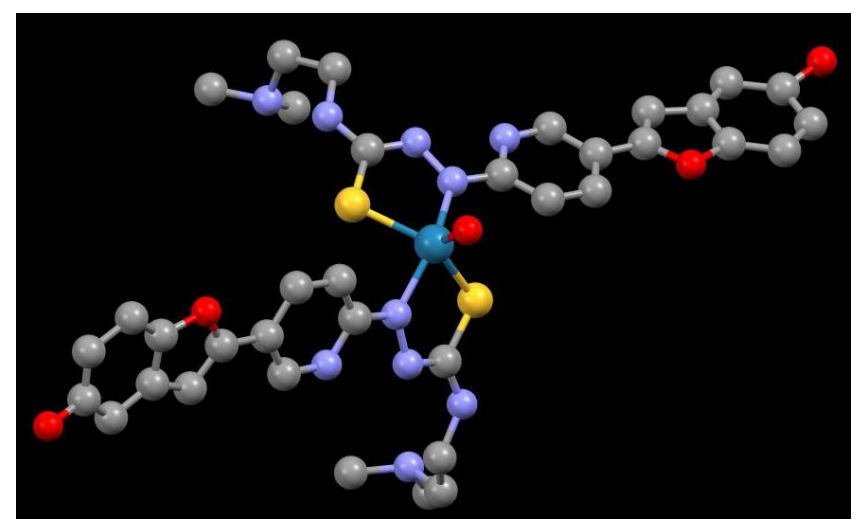




\section{University Library}

\section{- MINERVA \\ A gateway to Melbourne's research publications}

Minerva Access is the Institutional Repository of The University of Melbourne

Author/s:

Fletcher, SP;Noor, A;Hickey, JL;McLean, CA;White, JM;Donnelly, PS

Title:

Rhenium and technetium complexes of thioamide derivatives of pyridylhydrazine that bind to amyloid-beta plaques

Date:

2018-10-01

Citation:

Fletcher, S. P., Noor, A., Hickey, J. L., McLean, C. A., White, J. M. \& Donnelly, P. S. (2018). Rhenium and technetium complexes of thioamide derivatives of pyridylhydrazine that bind to amyloid-beta plaques. JOURNAL OF BIOLOGICAL INORGANIC CHEMISTRY, 23 (7), pp.1139-1151. https://doi.org/10.1007/s00775-018-1590-4.

Persistent Link:

http://hdl.handle.net/11343/282741 